\title{
Eliciting Lessons from Small- and Medium-Sized Enterprises for Resilience During and Following Complex Events: Longitudinal Data Collection (Wave 2)
}

\author{
Jennifer F. Helgeson \\ Juan F. Fung \\ Alfredo R. Roa-Henríquez \\ Ariela Zycherman \\ Payam Aminpour \\ Claudia Nierenberg \\ David T. Butry \\ Donna Ramkissoon
}




\title{
Eliciting Lessons from Small- and Medium-Sized Enterprises for Resilience During and Following Complex Events: Longitudinal Data Collection (Wave 2)
}

\author{
Jennifer F. Helgeson \\ Juan F. Fung \\ Alfredo R. Roa-Henríquez \\ Payam Aminpour \\ David T. Butry \\ Donna Ramkissoon \\ Office of Applied Economics \\ Engineering Laboratory \\ Ariela Zycherman \\ Claudia Nierenberg \\ Climate Program Office \\ National Oceanic and Atmospheric Administration
}

This publication is available free of charge from: https://doi.org/10.6028/NIST.DCI.003

May 2021

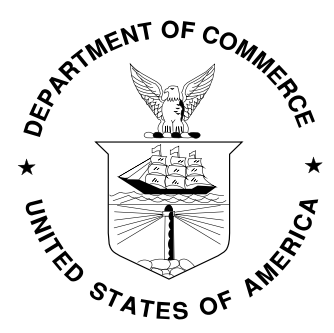

U.S. Department of Commerce Gina M. Raimondo, Secretary

National Institute of Standards and Technology James K. Olthoff, Performing the Non-Exclusive Functions and Duties of the Under Secretary of Commerce for Standards and Technology \& Director, National Institute of Standards and Technology 
Certain commercial entities, equipment, or materials may be identified in this document in order to describe an experimental procedure or concept adequately. Such identification is not intended to imply recommendation or endorsement by the National Institute of Standards and Technology, nor is it intended to imply that the entities, materials, or equipment are necessarily the best available for the purpose.

The NIST Data Collection Instruments series include questionnaires or survey instruments, interview guides, and other structured means of collecting data. Some of these instruments are designed for human subjects research focused on households, social institutions, and businesses. The instruments are approved by both NIST Institutional Review Board (IRB) and OMB/Paperwork Reduction Act.

National Institute of Standards and Technology Data Collection Instruments 003 Natl. Inst. Stand. Technol. Data Collect. Instr. 003, 133 pages (May 2021)

This publication is available free of charge from: https://doi.org/10.6028/NIST.DCI.003 


\begin{abstract}
In 2020, there were 22 natural disasters with losses exceeding \$1 billion each in the US (NOAA NCEI, 2021). Economic effects on the areas impacted directly were significant; Swiss Re estimated insured losses to be $\$ 83$ billion, making 2020 the fifth costliest year on record since 1970 (Swiss Re, 2020). Small- and Medium-sized Enterprises (SMEs) in areas vulnerable to these natural disasters and other extreme weather events (EWEs) are particularly noteworthy in the context of COVID-19. As COVID-19 conditions persist, the chances are high that populations around the US and the world already have and will continue to experience natural disasters (e.g., heat waves, floods, hurricanes, fire, and drought) during the period of virus transmission and into the period of recovery. In the "SME Complex Event Resilience Survey: Wave 1" Survey of US SME operators conducted in summer 2020, $29 \%$ indicated that they had experienced a complex event during the period March 13 to August 11, 2020 originating from natural disasters or EWEs during COVID-19.

This Data Collection Instrument (DCI) Report focuses on the longitudinal research approach taken by Department of Commerce researchers to study the impact of COVID-19 on SMEs and a subset thereof which had experienced an EWE before or during COVID-19. This second wave of data collection follows on from an initial wave of data collection. The Wave 1 summary data are reported upon in Helgeson et al. (2020a, 2020b) and the Wave 1 survey methodology is reported upon in Helgeson et al. (2020c). Methods and instruments used for the Wave 2 of data collection are presented in this DCI Report. This data collection was conducted online and combines quantitative and qualitative questions to document (1) the novel resilience-based mitigation actions employed during the COVID-19 pandemic by small- and medium-sized enterprises (SMEs), (2) challenges in implementing resiliencebased mitigation actions, (3) utilization of past strategies and approaches to provide assistance to the current situation, and (4) planned resilience and recovery actions and strategies. As such, the questions are framed specifically to COVID-19 pandemic conditions; however, many are generalizable to SME operators facing concurrent events, especially those that are compound and converging in nature. Results from this data collection are to be presented in future reports and articles; initial summary information is available in Helgeson et al. (2021a).
\end{abstract}

\title{
Key words
}

Adaptive capacity; built infrastructure; business recovery; business resilience; climate; community resilience; complex event; coping; COVID-19; extreme weather events (EWEs); Micro-, Small-, and Medium-sized Enterprises (MSMEs); mitigation; pandemic; resilience planning; Small- and Medium-sized Enterprises (SMEs); survey instrument. 


\section{Acknowledgements}

The authors wish to thank all those who contributed ideas and suggestions for this report. Special appreciation is extended to SME operators for their time spent answering the survey and their helpful insights on the challenges faced and innovations employed during COVID19.

The authors wish to thank all those who contributed ideas and suggestions for this report and the survey presented herein as well as all those who helped distribute the invitation to participate in the Wave 1 survey from which the longitudinal panel responses arose. Much appreciation is extended to Yating Zhang for her work on the initial sampling approach employed in Wave 1 and foundational work on verification of SME contact email addresses.

We are grateful to members of NIST's Office of the Associate Director for Laboratory Programs (ADLP) and NIST's Public Affairs Office (PAO) for supporting this research.

We appreciate the expert review of the IRB and PRA applications from Elizabeth Reinhart (NIST), Eyeisha Barron (NIST), and Anne Andrews (NIST).

Sincere thanks goes to Douglas Hilderbrand (NOAA), Elizabeth Rohring (NOAA), Joshua Barnes (SBA), Lynda Lowe (FEMA), Bridget Gonzales (MBDA), Efrain Gonzalez (MBDA), Frederico Mini (MBDA), and members of the Recovery Support Function Leadership Group's COVID-19 Data and Assessment Working Group.

Thanks to Douglas Thomas (NIST) and Matthew L. Malecha (NIST/TAMU) for time spent reviewing this document.

The report authors also wish to thank their families who supported their long hours of work from home on this quick turnaround survey effort and associated analysis and documentation. 


\section{Author Information}

Jennifer F. Helgeson, Ph.D.

Research Economist

Applied Economics Office, Engineering Laboratory

National Institute of Standards and Technology

100 Bureau Drive, Mailstop 8603 Gaithersburg, MD 20899-8603

Email: jennifer.helgeson@ nist.gov

Juan F. Fung, Ph.D.

Research Economist

Applied Economics Office, Engineering Laboratory

National Institute of Standards and Technology

100 Bureau Drive, Mailstop 8603 Gaithersburg, MD 20899-8603

Email: juan.fung@nist.gov

Alfredo R. Roa-Henríquez, Ph.D.

PREP Postdoctoral Fellow

Applied Economics Office, Engineering Laboratory

National Institute of Standards and Technology

100 Bureau Drive, Gaithersburg, MD 20899-8603

Email: alfredo.roahenriquez@nist.gov

Ariela Zycherman, Ph.D.

Social Scientist and Program Manager, Climate and Societal Interactions Division Climate Program Office, National Oceanic and Atmospheric Administration

1315 East-West Highway Suite 100

Silver Spring, MD 20910

Email: ariela.zycherman@noaa.gov

Payam Aminpour, Ph.D.

PREP Postdoctoral Fellow

Applied Economics Office

Engineering Laboratory

National Institute of Standards and Technology

100 Bureau Drive, Gaithersburg, MD 20899-8603

Email: payam.aminpourmohammadabadi@nist.gov

Claudia Nierenberg

Chief, Climate and Societal Interactions Division

Climate Program Office, National Oceanic and Atmospheric Administration

1315 East-West Highway Suite 100

Silver Spring, MD 20910

Email: claudia.nierenberg@noaa.gov 
David T. Butry, Ph.D.

Office Chief, Research Economist

Applied Economics Office, Engineering Laboratory

National Institute of Standards and Technology

100 Bureau Drive, Mailstop 8603 Gaithersburg, MD 20899-8603

Email: david.butry@nist.gov

Donna Ramkissoon

Administrative Office Assistant

Applied Economics Office, Engineering Laboratory

National Institute of Standards and Technology

100 Bureau Drive, Mailstop 8603 Gaithersburg, MD 20899-8603

Email: Donna.ramkissoon@ nist.gov 


\section{Table of Contents}

Abstract.......

Key words.

Error! Bookmark not defined.

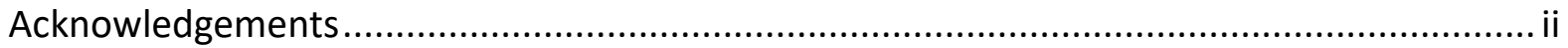

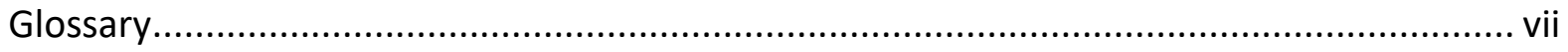

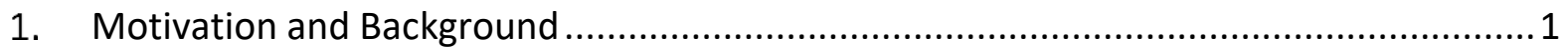

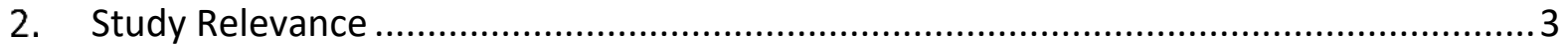

2.1. Relevant Partnerships and Cooperation ..................................................................... 3

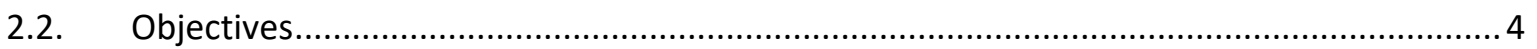

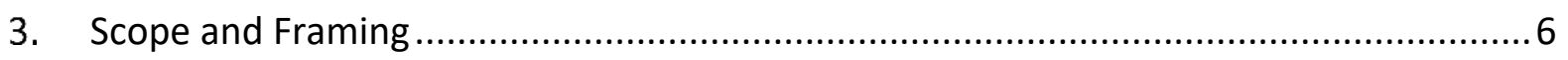

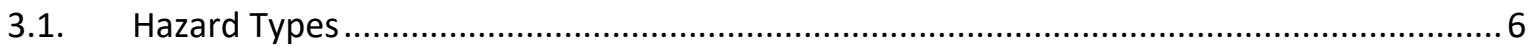

3.2. Complex Events, Impacts, and Recovery Capacity ...................................................... 7

3.3. SME Mitigation, Adaptation, and Coping ................................................................. 10

4. Sampling and Survey Development Procedures .................................................... 11

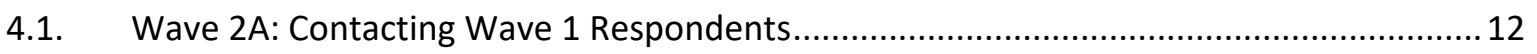

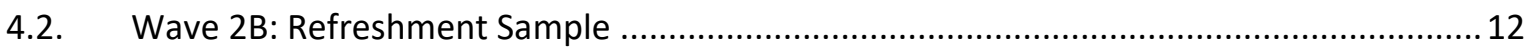

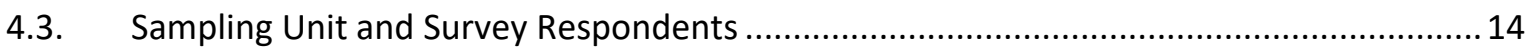

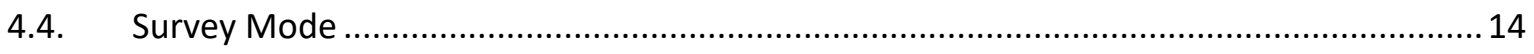

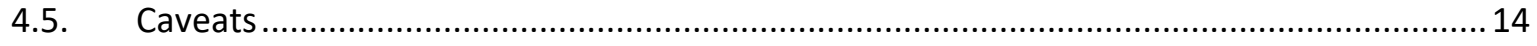

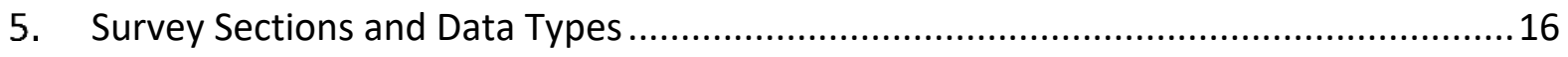

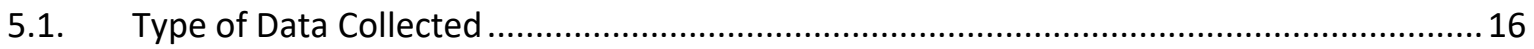

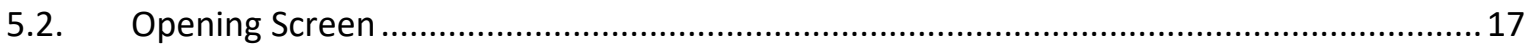

5.3. Opening Section - Current Business Status ............................................................... 17

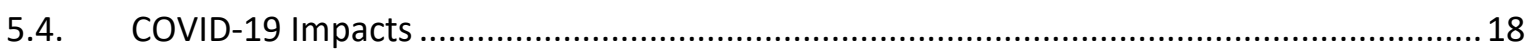

5.5. Natural Hazard and EWE Experiences.......................................................................... 18

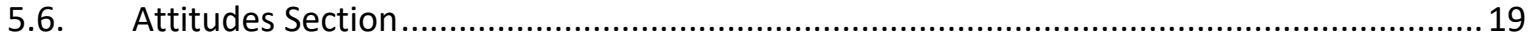

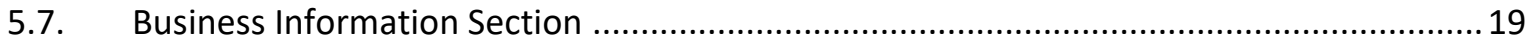

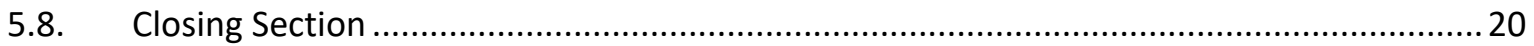

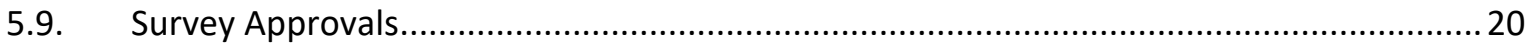

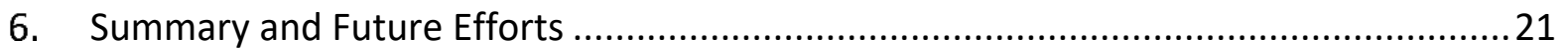

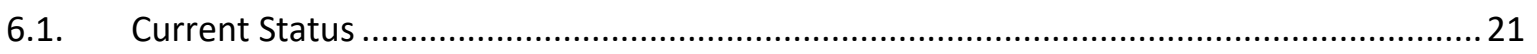

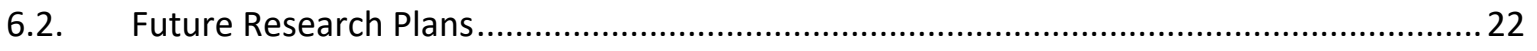




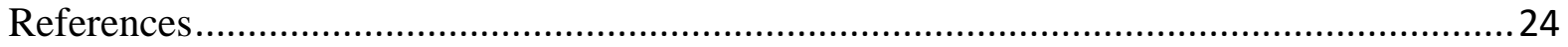

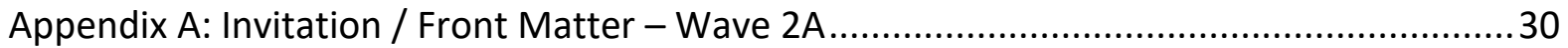

Appendix B: Invitation / Front Matter - Wave 2B ……................................................... 31

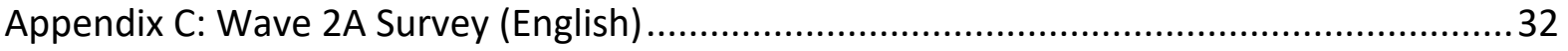

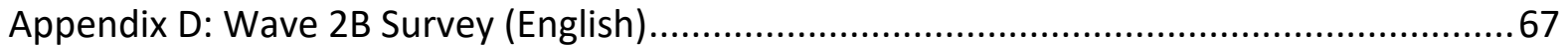

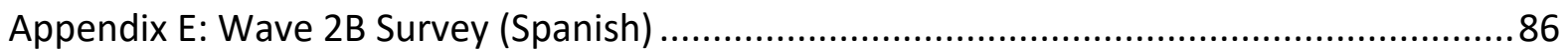

\section{List of Tables}

Table 1. Examples of covariate/idiosyncratic and acute/chronic shocks and stresses relevant to SMEs (by source, not impacts or effects)

Table 2. Sampled states by Census, NOAA, and FEMA regions for Wave 2B (i.e., refreshment sample)

\section{List of Figures}

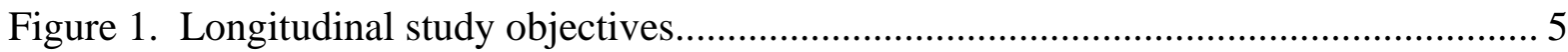

Figure 2. Components of impact risk at the individual SME level......................................... 9

Figure 3. Schematic of amplified impact based on pre-existing vulnerabilities.................... 10

Figure 4. Categories of relevance to SME operation and recovery status............................. 22 


\section{Glossary}

$\begin{array}{ll}\text { AEO } & \text { Applied Economics Office } \\ \text { COVID-19 } & \text { Coronavirus disease 2019 } \\ \text { EIDL } & \text { Economic Injury Disaster Loan } \\ \text { EWE } & \text { Extreme Weather Event } \\ \text { IRB } & \text { Institutional Review Board } \\ \text { MBDA } & \text { Minority Business Development Agency } \\ \text { NAICS } & \text { North American Industry Classification System } \\ \text { NOAA } & \text { National Oceanic and Atmospheric Administration } \\ \text { PIP } & \text { processes, institutions, and policies } \\ \text { PRA } & \text { Paperwork Reduction Act } \\ \text { POC } & \text { point of contact } \\ \text { RISA } & \text { Regional Integrated Sciences and Assessments } \\ \text { SBA } & \text { Small Business Administration } \\ \text { SBPS } & \text { Small Business Pulse Survey } \\ \text { SIC } & \text { Standard Industrial Classification } \\ \text { SME } & \text { Small- and medium-sized enterprise } \\ \text { WRN } & \text { Weather Ready Nation }\end{array}$




\section{Motivation and Background}

In 2020, there were 22 natural disasters with losses exceeding \$1 billion each in the U.S. (NOAA NCEI, 2021). Economic effects on the areas impacted directly were significant; Swiss Re estimated insured losses to be $\$ 83$ billion, making 2020 the fifth costliest year on record since 1970 (Swiss Re, 2020). SMEs in areas vulnerable to these natural disasters and other extreme weather events (EWEs) are particularly noteworthy in the context of COVID-19. As COVID-19 conditions persist, the chances are high that populations around the U.S. and the world already have and will continue to experience natural disasters (e.g., heat waves, floods, hurricanes, fire, and drought) during the period of virus transmission and into the period of recovery. In the "SME Complex Event Resilience Survey: Wave 1" conducted with U.S. SME operators conducted in summer 2020, $29 \%$ of respondents indicated that they had experienced a complex event during the period March 13 to July 28, 2020 originating from natural disasters or EWEs during COVID-19.

As COVID-19 conditions persist, the chances are high that populations around the US and the world will experience natural disasters (e.g., heat waves, floods, hurricanes, fire, and drought) during the period of virus transmission and into the period of recovery (e.g., Phillips et al., 2020). Small and medium-sized enterprises (SMEs) make up $44 \%$ of US economic activities and are the lifeline for many local economies. In fact, data from the Small Business Administration (SBA) indicates that small businesses create, on average, over 1.5 million jobs annually (SBA, 2019), and the employment growth of midsize firms has averaged $4.3 \%$ from 2012 to 2019 and has outpaced employment growth from large firms (NCMM, 2021).

This Data Collection Instrument (DCI) Report focuses on the longitudinal research approach taken by Department of Commerce researchers to study the impact of COVID-19 on SMEs and a subset thereof which had experienced an EWE pre- or during COVID-19. The second wave of data collection reported upon in this DCI Report took place December-February 2021. This second wave of data collection follows on from an initial wave of data collection reported upon in Helgeson et al. (2020a). Methods and instruments used for Wave 2 of data collection are presented in this DCI Report. This data collection was conducted online and combines quantitative and qualitative questions to document (1) the novel resilience-based mitigation actions employed during the COVID-19 pandemic by small- and medium-sized enterprises (SMEs), (2) challenges in implementing resilience-based mitigation actions, (3) utilization of past strategies and approaches to provide assistance during the current situation, and (4) planned resilience and recovery actions and strategies. As such, the questions are framed specific to COVID-19 pandemic conditions; however, many are generalizable to SME operator facing concurrent events, especially those that are compound and converging in nature.

Although there are significant limitations posed by and devastating impacts of COVID-19 that will affect the US and world economies for many years to come, the pandemic presents opportunities for research concerning complex events. Longitudinal tracking of SME operators' decisions, resources, perceptions, and recovery trajectories offer valuable insights to the value of anticipatory mitigation and adaptation planning. Studying SMEs in areas prone to natural disasters and EWEs as a subset of a larger national SME sample offers a chance to understand whether planning for one type of hazard may influence preparedness for a significantly different hazard: in this case, COVID-19. Additionally, as the period of COVID-19 transmission changes 
and SMEs become accustomed to a "new normal," insights as to the impact on future planning for business interruptions and limits on resources for such planning is critical. 


\section{Study Relevance}

There is utility in understanding multi-hazards that manifest as complex events from the concurrence of a pandemic and natural disasters. COVID-19 is unprecedented in terms of contagion levels of the virus and its variants (Indranil and Prasenjit, 2020), in level of global impact, and in length of disruptions to daily. Even existing pandemic recommendations for SMEs may not have been enough to prepare for this particular pandemic (Agility Recovery, 2019; CDC, 2017).

Preparation recommendations reflect one set of social norms existing before the current pandemic while social media, news articles, and responses from local, state and federal governments demonstrate the varying pressures of businesses, schools, health officials, healthcare workers, and the general public. Businesses are adapting with new practices (e.g., moving retail online, changing to take-out dining), employee support (e.g., advanced pay, unemployment application support), and responding to shifting norms in their local communities (e.g., closing without government prompting to prevent spread) (Huddleston Jr., 2020; Levenson, 2020).

Despite the significance of SMEs to the U.S. economy, there continues to be little information on how SME operators plan for, respond to, or learn from pandemics, especially at the firm-level (Burton et al., 2011; R. E. Watkins et al., 2008; R. J. Watkins et al., 2008). There have been surveys conducted that address SME operators and their experience during the COVID-19 pandemic; however, the majority are focused on economic impacts of the pandemic without consideration of complex events (e.g., Bartik et al., 2020; Buffington et al., 2020). Research focused upon SME resilience to natural disasters tends to be better established in the literature and offers relevant insights as to the response to business interruption and recovery of SMEs from the COVID-19 pandemic (e.g., Runyan, 2006; Torres et al., 2019). However, we are not aware of any national-level survey-based longitudinal research on the experiences of SMEs dealing with complex threats that arise from compound risks of natural hazards and pandemic conditions. The first wave of data collection took place in the summer of 2020 and is reported upon in Helgeson (2020a, b).

\subsection{Relevant Partnerships and Cooperation}

The main audience for this study and the associated survey results was envisioned to be federal partners and other entities that provide resilience-based assistance and guidance to SMEs, such as the Federal Emergency Management Agency (FEMA) and the Small Business Administration (SBA). Data collected through the Wave 1 survey in summer 2020 were meant to provide a basis for lessons learned for counterparts at appropriate federal agencies for them to frame and distribute SME-relevant guidance. Data garnered via the Wave 1 survey instrument were used as baseline information for development of the Wave 2 data collection instruments reported upon here. It is extremely rare to study a disaster event during the impact period and to trace recovery at the individual entity level, especially in the face of compound risks. The nature of COVID-19 has provided us with a unique opportunity to conduct two waves of data collection during the 
impact period, recognizing that recovery at the SME-level remains a work in progress and is idiosyncratic for a number of local and SME-specific reasons.

Related partnerships and collaborations are documented in NIST DCI002 (Helgeson et al., 2020). There are several known Federal consumers of Wave 1 data from this study, including, but not limited to the Minority Business Development Agency, NOAA Sea Grant Network, Women's Bureau, Department of Labor, and the US Small Business Administration. There are additional institutions outside of the Federal government that use the data, including the US Chamber of Commerce Foundation and local business chambers. Furthermore, briefing documents on this study have been requested for inclusion in the FEMA/Argonne Laboratory "COVID-19 Data and Assessment Portal" and "PreventionWeb," which is curated by the United Nations Office for Disaster Risk Reduction (UNDRR).

This longitudinal study, in combination with a NIST-NOAA collaboration started in late 2018 on place-based interdisciplinary SME recovery from natural disasters inspired additional investments within the Regional Integrated Sciences and Assessments Program (RISA), focusing on "Business Disruption and Resilience in the Context of Complex Climate Events.". One goal of this targeted funding effort, launched in early 2021, is to create a Community of Practice for social science projects that (1) give insight into the ways small and medium businesses are impacted by complex events and the unique ways they can become resilient to them and that (2) engage communities in developing relevant and usable research to support them in evaluating options. This work continues to move Federal interest in complex events at the SME- and community-level forward.

\subsection{Objectives}

This survey data collection is the second part of an ongoing longitudinal effort to address SME Complex Event Resilience. There are four interconnected objectives of the long-term effort, namely documentation and understanding of:

1. Novel resilience-based mitigation actions employed during the COVID-19 pandemic by SMEs,

2. Challenges in implementing resilience-based mitigation actions,

3. Use of past strategies and approaches to mitigate risks and adapt to the current situation, and

4. Planned resilience actions and strategies in the case of a complex event during the COVID-19 pandemic.

This effort is aimed at delivering relevant data to federal partners and other entities in providing guidance to SMEs on: 1. mitigation planning and adaptation for natural disasters during the pandemic and 2. disaster readiness strategies to cope with and recover from disruptions from the pandemic. 
An additional research goal is to advance best practices in data collection for SME resilience related to compound risks and complex events, especially under deep uncertainty. This report addresses this goal.

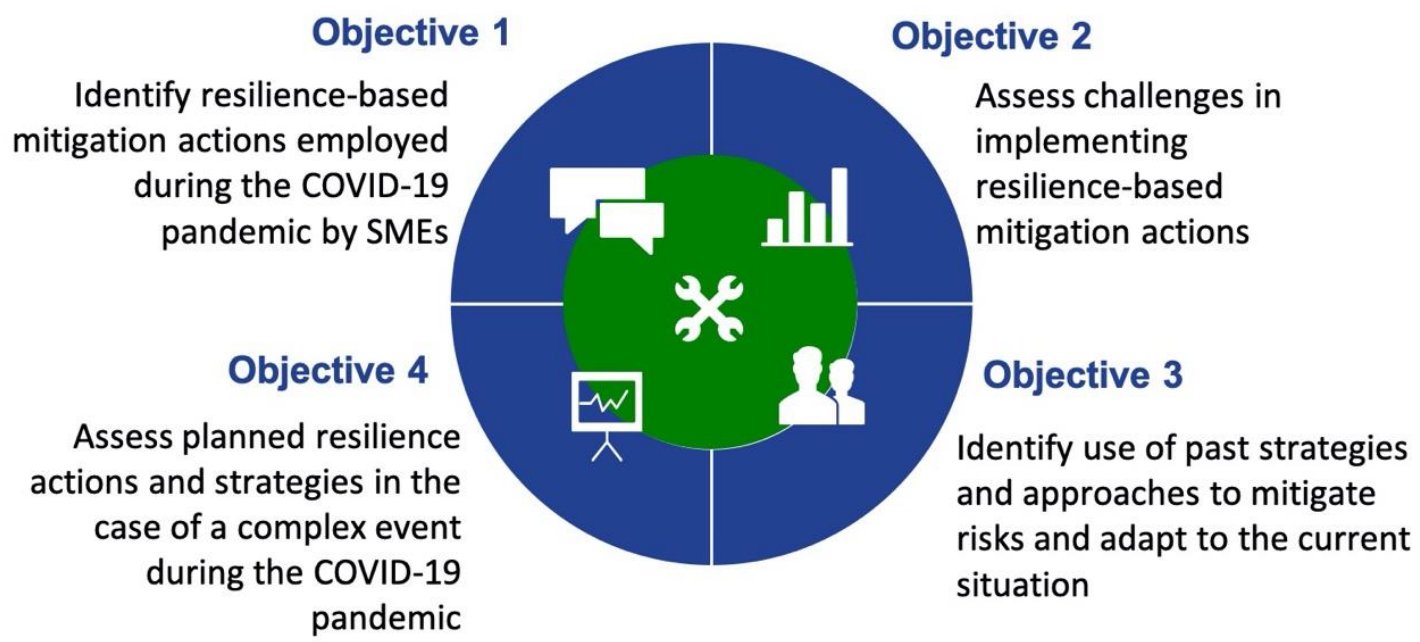

Figure 1. Longitudinal study objectives. 


\section{Scope and Framing}

The potential scope of this longitudinal study, and Wave 2, in particular, is broad given the extent of issues SME operators face in addition to addressing COVID-19 and/or natural disasters as well as other acute and chronic risk factors that create additional vulnerabilities.

This section reviews the conceptual framing of the study's assessment of complex events and additional vulnerabilities in terms of impact and long-term recovery on SME operators and employees as part of larger community resilience. This section also provides a summary of findings related to SME mitigation and adaptation in the face of business interruption. Findings specific to natural disaster and EWE disruptions are summarized and emerging findings on SME mitigation and adaptation in the context of COVID-19 that are especially relevant for inclusion as we ask about complex event impacts are noted.

\subsection{Hazard Types}

Hazard types considered in this longitudinal study and situated within a larger taxonomy of acute, chronic, covariate, and idiosyncratic hazards are detailed in Helgeson et al. (2020c) and are summarized in Table 1. For this study "we focus upon complex events and the effects that arise from addressing natural hazards while responding to pandemic conditions. Although COVID-19 and potential EWEs originate from separate causes, their impacts could coincide spatially and temporally adding an additional layer to current theorizing around preparation, response, and recovery in this category of spatially concurrent (related or unrelated) hazards" (ibid.).

In our study we specifically strive to differentiate between acute and chronic shocks and stressors. Chronic events are recurring and often can be expected; they may include events such as seasonal flooding and the influenza season. Acute risks are associated with less predictable hazard events that occur less frequently. In some literature, acute events are referred to as shocks (e.g., Marques, 2003; Kozel et al., 2008) and chronic events are referred to as stressors; however, for our framing, chronic events can manifest as a series of shocks that cause long-term stress.

Furthermore, we acknowledge that these events occur within the dimensions of common risks, or not, across entities. To this point, an idiosyncratic risk refers to the particular experience of a given SME operator and is typically unrelated to the risk(s) faced by geographically collocated SMEs. In contrast, covariate risk refers to the experience of multiple SME operators in the same region facing largely similar objective risks, the impacts of which may be moderated by mitigation, adaptation, and/or coping capacities and choices.

The impacts of COVID-19 continue to affect the ability of practitioners and communities to prepare for, cope with, and respond to natural disasters, including EWEs. In particular, COVID19 may amplify or exacerbate risks to SMEs associated with a wide range of natural hazard types, as well as affect SMEs owner/managers' option set of practical strategies to mitigate associated risks. Complex events can result from multiple hazards, often through a complex combination of both natural and human-made causes. 
Furthermore, in Wave 2 of this study we pay increased attention to potential sources of the social amplification of risk through existing vulnerabilities pre-COVID-19 and those increased during the pandemic.

Table 1. Examples of covariate/idiosyncratic and acute/chronic shocks and stresses relevant to SMEs (by source, not impacts or effects) (Helgeson et al., 2020c)

\begin{tabular}{|c|c|c|}
\hline & Idiosyncratic & Covariate \\
\hline Acute & $\begin{array}{l}\text { - Death of a family member / } \\
\text { employee } \\
\text { - Illness } \\
\text { - Loss of supplier(s) } \\
\text { - Social exclusion/ discrimination } \\
\text { - Crime/ violence } \\
\text { - Theft }\end{array}$ & $\begin{array}{ll}\text { - } & \text { Earthquake } \\
\text { - } & \text { Hurricane } \\
\text { - } & \text { Tornado } \\
\text { - } & \text { Dry spells/erratic rain } \\
\text { - } & \text { Market shock (price volatility) } \\
\text { - } & \text { Disease outbreak }\end{array}$ \\
\hline Chronic & $\begin{array}{l}\text { - Social exclusion/ discrimination } \\
\text { - Long-term illnesses }\end{array}$ & $\begin{array}{l}\text { - } \text { Drought } \\
\text { - } \text { Climate change/variability } \\
\text { - } \text { Land degradation } \\
\text { and economic wellbeing }\end{array}$ \\
\hline
\end{tabular}

\subsection{Complex Events, Impacts, and Recovery Capacity}

While most frameworks identify risk as a primary concept in disaster management and resilience planning, they fail to explicitly include the dimensions of risk which a given SME may face.

By considering $\mathrm{R}=f(\mathrm{~V}, \mathrm{H})$, risk of a given impact, as a function of vulnerability ( $\mathrm{V}$ ) and hazard (H) (Cardona et al., 2012), the need to both reduce hazard occurrence and address SME (and community) vulnerability in the context of these events is clear. Hazards encompass the whole gamut of adverse events and circumstances, including natural, political, economic, and technological. Of course, in the case of complex events, neither the hazard nor the vulnerability is straightforward to specify, much less measure. Thus, risk mitigation strategies that are domain general are likely the most efficient when the nature of potential hazards is characterized by deep uncertainty and the SME operator's resources and assets are constrained.

Vulnerability may include consideration for collective assets, resources, and strategies adopted by the SME operators pre- and post- event impact. Leveraging the livelihoods perspective of vulnerability (Sarkar et al., 2019), assets and resources can be categorized as technological/physical, environmental/natural, economic/financial, human/social, and political. However, the effectiveness of SME operators' assets and resources is shaped (i.e., enhanced or constrained) by framing processes, institutions, and policies (PIPs) that are typically external to the SME operator's direct control. A cogent example of a PIP constraining an SME operator, and potentially deepening vulnerability, is ineligibility of the SME for a loan or insurance payout. Additionally, there are some complications from the fact that SME operators act upon perceived 
risks, which is sensitive to learning, agency, and flexibility of resources and assets (Helgeson et al., 2021b), but also uncertainty in perspectives, expectations, and relative risk tolerance. Wave 1 of this study recorded a number of less-than-optimal financial decisions reported by SME operators motivated for their care for their employees, uncertainty surrounding PIPs, and perceptions about the complex event they faced (e.g., expected end-date of COVID-19 transmission).

Livelihood resilience is a policy concept in development context research that emerges across various disciplines (Tanner et al., 2015), but is not often applied in the developed country context. Generally, this view recognizes resilience as a process that tackles a wide range of shocks, vulnerabilities, and stresses across communities, but is couched in access to meaningful and effective work and wealth (CDC Foundation and Wellbeing Trust, 2020). Resilience offers an important agenda for working as part of an integrated and comprehensive approach to assessing and addressing factors that undermine communities' and countries' resilience, including climate risk, environmental sustainability, and social inequalities or exclusion (UN, 2013). The main effect of natural disasters and EWEs is on the livelihood of the resource-poor and limited across the world and these impacts filter back to the communities in which they are situated.

There are a number of concepts relevant to the impact felt from a complex event by an SME operator and the wider community (i.e., via employees and customers). The concepts in the context of SMEs most relevant to the design of our Wave 2 survey instruments are noted below. In this context we assume that the compounding event is classified as a shock.

Capacity is a combination of all the assets and resources available within an SME and afforded to the SME by a community, society, or organization that can reduce the level of risk, or the effects of a disaster on an SME. Capacity may include physical, institutional, social, or economic means as well as skilled personnel.

Adaptation measures are structural and non-structural measures undertaken to limit the impact of a hazard event that are enacted once the event impact has begun. Adaptation may be classified as anticipatory

Mitigation measures are structural and non-structural measures undertaken to limit the risk of exposure and/or the potential adverse impact of hazard events. These mitigation actions may be preparedness or prevention based.

Preparedness activities and measures are taken in advance to ensure effective response to the impact of hazards, including insurance purchases.

Prevention activities provide outright avoidance of the adverse impact of hazards and means to minimize related disaster impacts.

Coping measures are the choices made by SME operators given available resources and abilities to face adverse consequences of disaster impacts that could lead to a disaster. 
Inherently these may be adaptation measures that preempt future SME growth and capacity to continue business.

Response relief measures constitute the provision of assistance or intervention during or immediately after a disaster to meet the needs of affected SMEs. These are generally in the form of PIPs and may be short- or long-term in duration.

Resilience characterizes the capacity of the SME as an organization to adapt by resisting or changing in order to reach and maintain an acceptable level of functioning and structure. Typically, this characteristic is tied to time of full recovery of the physical structure, function of the SME, or net revenue of the SME post-event.

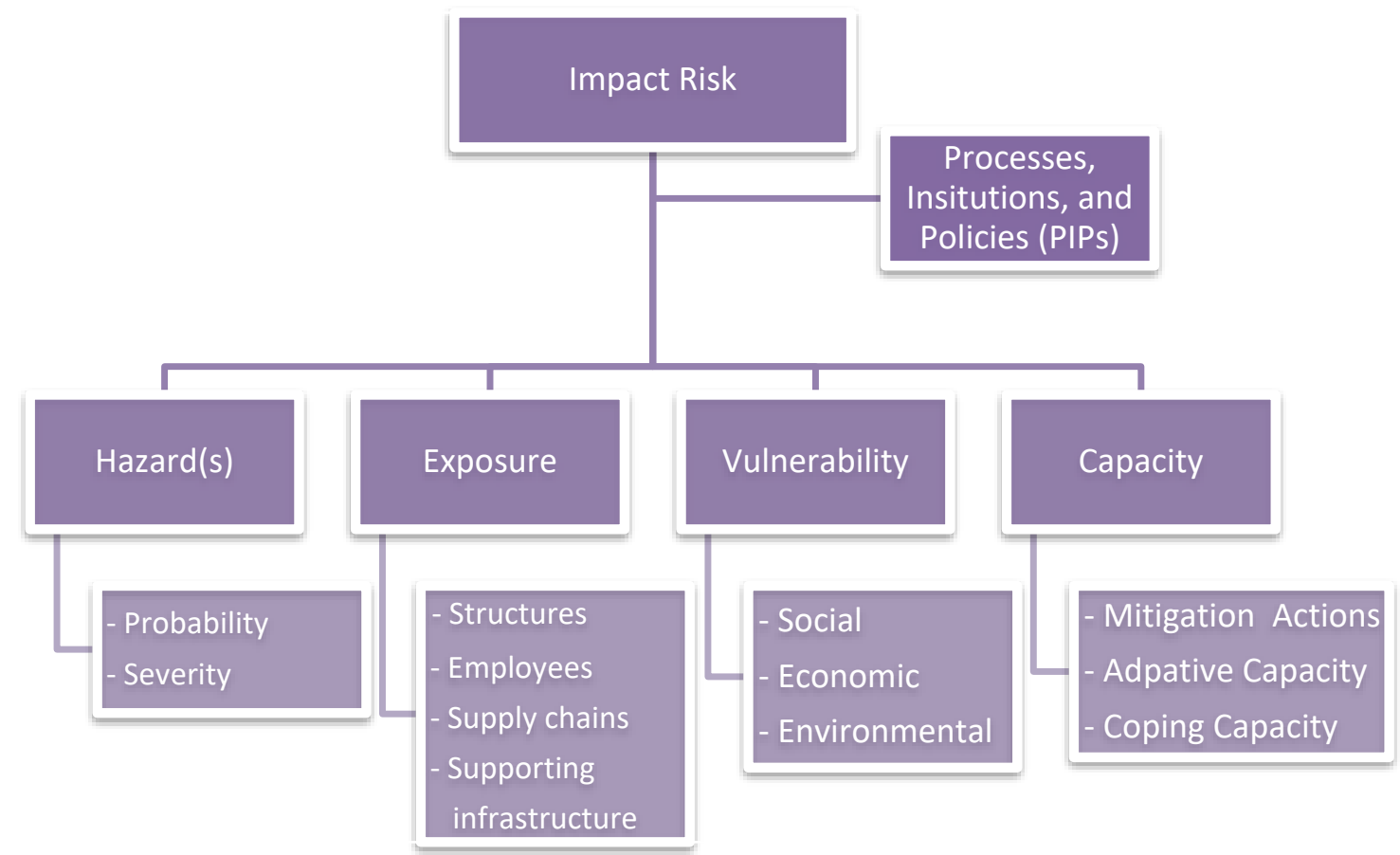

Figure 2. Components of

impact risk at the individual SME level.

Disaster risk reduction literature often highlights the importance of focusing less on the potential expected characteristics of the hazard event and more on the vulnerabilities and physical exposures (Lavell et al., 2012), which may be in the form of stressors, that drive the ultimate impact of a disaster on an SME's structure, assets, and human capital. This is especially significant in the case of complex hazards with deep uncertainty. As shown in Figure 2, an SME with greater social vulnerability will likely have amplified impacts from a complex event. Furthermore, vulnerability in addition to a singular event can also constitute a complex event. Handmer and Dovers (2007) note that given certain risks and hazards, a better understanding of vulnerability would allow for different outcomes for a given population. Furthermore, if we better understand vulnerability and this is adequately predictive, livelihoods may more easily be protected across various singular and complex events through the support of existing institutions in disaster prevention (Cannon et al., 2003). 


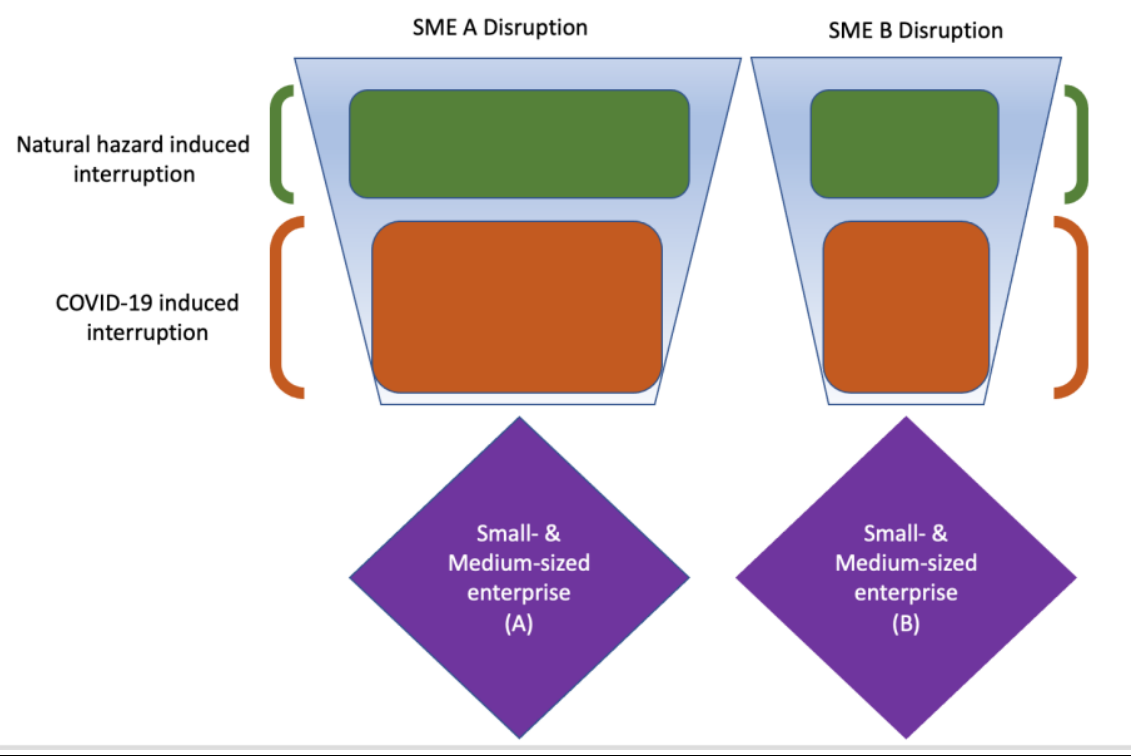

Figure 3. Schematic of amplified impact based on pre-existing vulnerabilities; SME A is more vulnerable than is SME B.

Additional discussion exists around transferring covariate risk from the SME or community to an institution or agency that is better equipped to handle it, such as the government via social safety nets or an insurance agency. In both example cases, some risk elements are effectively shifted from the vulnerable SME operator. Some form of residual risk always remains, and therefore is a process; ideally this feedback loop engenders a specific process from risk reduction, to risk transfer, and finally prudent risk-taking. Vulnerability that is associated with the social amplification of risk is often overlooked as an underlying risk driver in programming and analyses that is not easily addressed by prevention and mitigation, while addressing vulnerability directly may greatly reduce impacts of natural hazards and EWEs. Figure 3 provides a schematic presentation where SME A is more vulnerable than SME B ahead of the occurrence of COVID19 and/or a natural hazard. In turn, the impacts on SME A are greater.

\subsection{SME Mitigation, Adaptation, and Coping}

The option set of potential mitigation strategies relevant to a given SME depends on the type of risk involved, e.g., acute or chronic, singular or complex. For example, Wedawatta and Ingirige (2012) observed that in the context of persistent flooding, SME operators implement different property-level mitigation measures as well as more generic business continuity/risk measurement steps to achieve a desired protection level. Yet, many mitigation and adaptation measures that are relevant to flood-associated hazards are not relevant to SME COVID-19 response (e.g., CDC, 2020), but adapting more generic business continuity tactics in place may help in the context of COVID-19. We see evidence of this claim in the Wave 1 data collected (Helgeson, 2020a).

Surveys of SME operators that directly address COVID-19 interruptions report mixed results on adaptative behaviors and expectations for recovery. Despite the strain that COVID-19 has exerted on businesses, the proportion of midsize companies' executives who think the pandemic 
will have large long-term negative impacts has decreased; however, these respondents continue to struggle with uncertainty and consider their main challenge maintaining relationships with customers and managing workforce disruptions (NCMM, 2021). The US Census Small Business Pulse Survey demonstrates that from spring 2020 to winter 2020, small business operators' expectations of a return to normal operational levels is at extremes, largely by the percentage of businesses in a given sector that were not affected by the pandemic or already returned to "normal" by winter 2020 (Buffington et al., 2021).

Although it is clear that businesses continue adapting their processes while making their operations more flexible, businesses have also benefited from past experiences with natural disasters to implement several actions that have helped them to cope with the impacts of COVID-19 (Helgeson et al., 2021b).

\section{Sampling and Survey Development Procedures}

The inherent limitations in conducting SME research at the enterprise-level are described in Helgeson et al. (2020c). Nearly all such survey work tends to use convenience or representative samples, as opposed to a randomized sampling strategy (e.g., Corey and Deitch, 2011; Lam et al., 2012; Lesage et al., 2011).

Given the constraints posed by the COVID-19 transmission period the entirety of this longitudinal study is planned to be conducted online. Lavrakas (2008) indicates that Internetbased surveys are one of the most predominant survey types due to easiness of use, cost, and rapid response times. At the same time, however, this mode of survey can be an important source of bias because not all potential respondents always have access to the Internet, their recruitment is characterized by self-selection, and there tends to be significant demographic difference between those individuals who decide to participate vs those who do not, leading to "undercoverage bias" (Bethlehem, 2010). Given that $93 \%$ of American adults use the internet today (Pew Research Center, 2021a), the issue of "under-coverage" may not be so problematic. This can generally be solved by properly designing online surveys that are accessible and readable not only on computers and tablets, but also on smartphones (Helgeson et al., 2020c). However, selfselection may pose serious issues to the reliability of the survey. In this particular case, there is inherent sample selection bias due to the impacts of the pandemic, with struggling or failing SMEs less likely to respond to the survey (see e.g., Sadiq, 2011). Both sources of bias, nonetheless, may reduce the ability to generalize survey findings (DuGoff et al., 2014).1

Furthermore, Wave 2 of data collection comprised of two instruments and two samples. The first, referred to herein as Wave 2A, is a true longitudinal sample that contacted respondents from Wave 1 who indicated that they would like to be contacted again for follow-up information and participation. The second, referred to herein as Wave $2 \mathrm{~B}$, was a refreshment sample and is discussed at length in Section 4.2.

\footnotetext{
${ }^{1}$ Typical approaches to correct for these sources of bias include propensity score methods and other survey weighting methods, as well as survey design that draws from a larger, known sample (Schonlau et al., 2009; Bethlehem, 2010; DuGoff et al., 2014). This is beyond the scope of this publication.
} 


\subsection{Wave 2A: Contacting Wave 1 Respondents}

Wave 2A respondents all answered Wave 1 of this longitudinal study. These individuals all indicated at the end of the Wave 1 online survey that they were willing to be contacted to learn more about the Wave 1 results and to consider continued participation in Wave 2. These respondents were contacted by email and self-selected into participation in Wave 2. An example of the email communication provided to Wave 2A respondents is in Appendix A. Furthermore, these respondents were all provided with the summary report and the full report arising from Wave 1 aggregate data trends.

\subsection{Wave 2B: Refreshment Sample}

The use of refreshment samples in longitudinal studies involving panel data is fairly typical. "Panel studies typically suffer from attrition, which reduces sample size and can result in biased inferences" (Deng et al., 2013). Ultimately, a new sample of respondents given the survey at the same time as a subsequent wave of the panel offer information that can be used to diagnose and adjust for bias due to attrition. Additionally, the refreshment sample, in this case the Wave 2B sample, can be used to bolster the overall panel sample in data analysis given that response characteristics are not statistically different from the original Panel (i.e., Wave 2A respondents).

Furthermore, the use of a refreshment sample in this type of research allows us to explore the extent of recall bias relevant in collecting data after the initial impact stage. This may have implications for future data collection and field deployments after a natural hazard which typically poses tension between the efficacy of burdening SME operators during initial recovery stages and the concern that perishable data will be lost without near-term (in-person) collection.

The Wave 2B respondents were derived in the same manner as respondents to Wave 1. The contact information for US businesses was obtained from USBizData.com. Each record in this list provides information on a business name, business physical address, a specific contact at the business, role of the contact within the business, business email address specific to the identified contact, and other business characteristics (e.g., number of employees). Additionally, USBizData.com provides information related to the Standard Industrial Classification (SIC) code, which for practical purposes was translated to the corresponding North American Industrial Classification System (NAICS) code associated to each business.

It is also important to mention that the main objective in Wave $2 \mathrm{~B}$ was to collect additional information from businesses in economic sectors that were not surveyed in Wave 1 in addition to adding to the sample using the original sectors. The refreshment sample aimed to focus on SMEs with NAICS 54 (Professional, scientific, and technical services) and 72 (Accommodation and food services) in the states targeted in Wave 1, which have been largely impacted by COVID-19related restrictions. The information collected in Wave 2B comes from the same States specified in Table 2 in Helgeson et al. (2020c). In addition, Wave 2B included seven additional states prone to the occurrence of natural hazards based on the SHELDUS database, which lists counties for each state that suffered losses due to thunderstorms, hurricanes, floods, wildfires, and tornados from 1960 to the present; see Table 2. As with Wave 1, all counties that experienced a natural disaster at least once since 1960 were selected for Wave 2B. In general, in the additional 
seven States, Wave 2B focused on surveying SMEs in the construction sector (NAICS 23), manufacturing (NAICS 31-33), Professional, scientific, and technical services (NAICS 54), and Accommodation and food services (NAICS 72).

Businesses were contacted by e-mail2. The data was then filtered by number of employees, counties, North American Industrial Classification System (NAICS) codes, and the position of contacts within their respective SME. The geographic regions of interest were initially determined through an attempt to obtain additional proportional data for all FEMA Emergency regions, NOAA climate regions (Karl \& Koss, 1984) and the four high-level Census geographic regions (US Census Bureau, 2018): Northeast, South, Midwest, and West.

Table 2. Wave 2B sampled states by Census, NOAA, and FEMA regions for Wave 2B (i.e., refreshment sample)

\begin{tabular}{|c|c|c|c|c|}
\hline State & Census region & NOAA region & $\begin{array}{c}\text { FEMA } \\
\text { region }\end{array}$ & Natural hazard types $^{\text {a }}$ \\
\hline $\mathrm{CO}$ & West & Southwest & 8 & $\begin{array}{c}\text { Flood, fire, coastal storm, snow, severe } \\
\text { storm }\end{array}$ \\
\hline $\mathrm{KS}$ & Midwest & South & 7 & Severe storm \\
\hline $\mathrm{NJ}$ & Northeast & Northeast & 2 & Hurricane, severe storm \\
\hline $\mathrm{OH}$ & Midwest & Central & 5 & Severe storm, snow \\
\hline $\mathrm{OK}$ & South & South & 6 & Severe storm, fire \\
\hline $\mathrm{PA}$ & Northeast & Northeast & 3 & Flood, severe storm, hurricane \\
\hline WI & Midwest & $\begin{array}{c}\text { East North } \\
\text { Central }\end{array}$ & 5 & Severe storm, flood, drought \\
\hline
\end{tabular}

a Source: https://www.adt.com/natural-disasters/declaration-analysis

An introductory email letter was sent to the determined point-of-contact (POC) for each SME location in the sample. The letter was directed to the individual with the unique SME name and the POC's first name was used. This cover letter invited participation in the survey and described the goals of the research, described consent (and its revocation process), how collected data will be used, and promised anonymity. Additionally, the OMB clearance statement was presented to the potential respondent. A sample of this front matter is provided in Appendix B. The presented letter differed across respondents; each email was addressed directly to the POC for the business and the potential respondent was provided a unique survey link. In this manner, we can approximate response rates.

\footnotetext{
2 Email addresses were verified using the MillionVerifier ${ }^{\mathrm{TM}}$ tool, an online email verification tool that checks email syntaxes and DNS servers and creates an SMTP connection with the recipients' server to find out if the email accounts exist. The tool is accessible from https://www.millionverifier.com/
} 


\subsection{Sampling Unit and Survey Respondents}

Respondents to this data collection include owners or managers of a business ${ }^{3}$ at a single, given geographic location. Previous research suggests that interviewing owners and managers provides the appropriate level of analysis to understand business culture (Augier and Teece, 2009; Grinyer and Spender, 1979; Schindehutte and Morris, 2001). This also assumes that decisions that define the SME and its employees have to ultimately be made at the organizational "top," at least at a single location; thus, we refer to the respondents in general terms as SME operators. The single location is important in this type of research since acute and idiosyncratic events differ largely by geography, especially for natural disasters. Even though SMEs owned or franchised by larger corporate entities may be guided in their preferences and plans, local conditions require some level of local decision-making.

The Wave 2A survey instrument was offered only in English, as the panel respondents who opted-in all felt comfortable answering in English. The survey instrument Wave 2B was translated to Spanish and respondents could select whether they answered in English or Spanish.

\subsection{Survey Mode}

Following the procedures employed in Wave 1 of data collection and given continued limitations faced due to the social distancing requirements of COVID-19, this data collection was conducted entirely online using internet-based survey instruments.

Internet-based surveys are one of the most predominant survey types due to ease of use, cost, and rapid response times (Lavrakas, 2008). This choice of mode directed the sampling approaches employed. It should be noted that internet-based surveys can be subject to significant bias resulting from under-coverage and self-selection. Yet, for a national-level survey this is a logical way to contact potential respondents. Not all SME operators have access to the internet, and there tends to be significant demographic difference between those who do and do not. The online instruments were designed in a manner that made them accessible (i.e., readable) on computers, tablets, and smartphones.

\subsection{Caveats}

At the time of the COVID-19 pandemic, online surveys lend themselves well to this "new normal," when more aspects of people' lives have moved online, and there has been an unprecedented digital surge and a sharp jump in the uses of the Internet. However, our online surveys were associated with some important limitations. In the survey protocol described herein, surveys were subject to the relationship between the sample and the population being unknown. For example, there is constant attrition of SMEs and some researchers suggest that checking social media, such as Yelp, is the most precise way to determine SMEs that go out-ofbusiness, especially during COVID-19. As such, there is no theoretical basis for computing (or

\footnotetext{
${ }^{3}$ Although a firm is usually referred to in the literature as a corporation or large enterprise with multiple business locations, here we use the terms "firm," "business," and "organization" as synonymous.
} 
reporting) a margin of sampling error and thus for estimating the true representativeness of the sample.

Ideally, survey sections would be randomized across respondents. The limitations of the platform used for data collection did not offer this option.

Additionally, some people and organizations still struggle with, or do not feel comfortable going online. Given that survey respondents were self-selected, the surveys were self-administered, and the fact that some SME operators did not feel comfortable taking the survey online (e.g., particularly those SME operators without Internet access, with no or limited English literacy, or SMEs in information and technology sectors with cybersecurity concerns), they might not have the opportunity to opt-in to participate. Future collaborations with those agencies and institutions which serve these populations would

In 2020 it was estimated that $85 \%$ of adults in the US own and use at least one smartphone with internet capability; for the age group 30-49 years it is $95 \%$ (Pew Research Center, 2021b). With this in mind, our survey displays were optimized for use on smart phones.

Furthermore, the surveys might be completed by SME operators who took a specific interest in the subject (e.g., those that suffered the greatest interruptions or struggled to adapt). Therefore, SMEs with lesser interruption and may be less likely to participate and therefore were potentially underrepresented in our samples. 


\section{Survey Sections and Data Types}

Survey sections are not titled/named in the Wave 2A or Wave2B survey instruments as viewed by respondents online, but are rather used for reference purposes in this discussion and between researchers during the survey development and data analysis. At the start of each section, there is a brief description of the section to help the respondent understand the type of questions to follow and the researchers' rationale in asking for the information.

For the most part, question responses are closed-ended; however, in several responses there is space for qualitative responses, especially when the option "other" is chosen by the respondent.

Below we provide a brief description of each specific survey section in the order they appear in the survey instruments. The two survey instruments are largely similar. The Wave $2 \mathrm{~A}$ instrument collected data for the period from August 1 to the "present" when the survey was conducted (i.e., December 2020-February 2021). The Wave 2B instrument sought to collect data relevant to the period August 1 to the present (i.e., January-February 2021) as well as data comparable with the survey instrument used in Wave 1 in terms of timeframe (i.e., March 13-August 1, 2020).

The full survey instrument for Wave 2A respondents is provided in Appendix C. The full survey instrument for Wave 2B respondents is provided in Appendix D (English) and Appendix E (Spanish).

All questions in the survey instruments are optional; the respondent may skip any single or combination of questions. Additionally, there is some skip-logic incorporated within the survey instruments. Thus, not all respondents are asked to answer all questions.

\subsection{Type of Data Collected}

Measuring resilience trajectories over time relies on both objective and subjective measures. Objective measures are directly observable data related to a shock or stressor. Some examples include rainfall data and losses of infrastructure or other assets; generally, they can be standardized and are widely accepted, even when they are self-reported.

SMEs and communities experience shocks and stresses differently based on context; subjective measures capture these unique perceptions and experiences. Additionally, at the individual entity level, objective measures can be challenging to obtain during and immediately following a disaster, acute or chronic. Subjective measures depend upon self-reported qualitative and qualitative survey data. These tend to be less standardized than objective measures, but focus on experiences, perceived severity, recovery capacity, and coping strategies. Through development of scales and detailed response guidance subjective questions (e.g., close-ended questions) can be increasingly standardized.

Subjective measures can be used as substitutes for objective measures or as complements to objective measures to provide an alternative perspective. Typically, subjective measures may include more bias, but they capture unique personal experience and perceptions that may provide insights into subsequent behavior.

There is data collected that is objective in nature - though subjective to perception - throughout the survey, such as the change in employee numbers and gross revenue. However, these data are all subjective in the sense that they are subject to self-reporting. 


\subsection{Opening Screen}

The opening screens of the Wave 2A and Wave 2B surveys reiterate information that was provided in the invitation to participate, as discussed in Section 4. In the case of Wave 2A, we thank the respondent for their participation in Wave 1 and continued interest in participation.

It is important that all relevant information about what is being requested of the respondent and participation consent is fully understood. This front matter provides an overview of the data collection goals and indicates how the respondents' information will be used. The OMB number is also included.

It is good practice to acknowledge the challenges COVID-19 continues to present for SME operators and employees. Furthermore, as with most events that affect not only the SME, but also potentially the household of the owner/manager and the wider community at large, COVID19 is no doubt creating worry for the respondent in many realms of their life, both professional and personal. Thus, the researchers were certain to acknowledge the value of the respondents' time and acknowledge their potential concerns and struggles.

This front matter also provides some directions for how the respondent should ideally interact with the survey should they opt to participate. For example, it indicates that the respondent should answer from the perspective of a single business location (i.e., street address location), should their company have multiple locations. The OMB Control number is clearly provided. The researchers provide a clear point of contact (POC) at NIST should the respondent need additional clarification, have questions they want answered, or concerns that they'd like to register. This initial scene text reads as though it is a letter from the NIST POC which makes it a more genuine invitation for the respondent to engage.

\subsection{Opening Section - Current Business Status}

The opening survey section of both survey instruments asks the respondent to indicate the current status of their business.

The survey branches off? based on the response to this question. If the respondent indicates that their business is permanently or temporarily closed, there is a short section that follows that asks additional details about the perceived source of/reason for closure. In particular:

- When the closure took place;

- Whether the closure is related to COVID-19;

- If the business experienced issues other than COVID-19 that contributed to the closure;

- Any adaptive measures taken before the closure;

- Expectations of whether the business will open again.

The survey then skips to the closing section and thanks the respondent for their time and asks them if they'd like to be contacted with findings from Wave 2 and to participate in future survey waves. Then the survey terminates for this group of respondents.

If the respondent indicates that their business is still operating, a different set of questions are presented. These questions address impact and adaptation due to COVID-19 specifically, 
discussed in Sec. 5.4, natural hazard experience, discussed in Sec. 5.5, and attitudes about the future, discussed in Sec. 5.6.

\subsection{COVID-19 Impacts}

This section asks the respondent to describe the impacts of COVID-19 on their business. For respondents of the Wave 2A survey instrument these questions are asked for the period August 1, 2020 to the present. At the time the survey was live the "present" was December 2020.

Respondents of Wave 2B were asked to respond for two time periods: March 13, 2021 to August 1, 2021 and August 1, 2020 to the present. At the time the survey was live the "present" was January 2021.

This section asks respondents to consider the following questions for the timeframes relevant to the given survey instrument:

- How would you describe the impact you are currently experiencing from COVID-19?

- What are the most important factors that influenced the choice of whether to resume operations or to continue operations if they never ceased?

- How has the COVID-19 pandemic impacted the operation of your organization?

- What is the approximate percent change in employees at your business compared to this time LAST year?

- The financial assistance applied for and received is asked in both Wave 2A and Wave 2B. The researchers separate the respondent applying for different financial assistance across source types and the assistance received (or not) by the SME.

- Any adaptation actions the respondent has started or continues to do to address the COVID-19 pandemic.

This section contains a hypothetical question to help gauge whether the respondent believes they would have made different choices in terms of adaptation and coping with COVID-19 related impacts on their SME.

\subsection{Natural Hazard and EWE Experiences}

This section asks the respondent to indicate past experiences that the SME may have with natural hazards and/or EWEs; the respondent may select multiple hazard types. Experience with these types of events during the COVID-19 transmission period are asked for the time periods relevant to Wave 2A and Wave 2B. The researchers control for those SMEs that may have experienced a natural disaster since the start of the COVID-19 pandemic using skip-logic to understand response to such an event. These respondents are asked:

- Whether the response to the event(s) was impacted by COVID-19;

- How the impact of the event(s) impacted the business compared to the impact of similar events pre-COVID-19 and whether the impact was greater than in the past because of the nature of the natural hazard or EWE as opposed to the compounding effects from COVID-19. 
A set of questions in this section ask the respondent to consider the extent to which preparedness actions taken in the past and present may cross domains in the respondent's opinion. In particular:

- Whether actions taken by the SME to prepare for natural hazards in the past have helped address the impact of COVID-19 felt by the SME;

- Whether the respondent plans to adopt any practices used during the COVID-19 pandemic in anticipation of future natural hazards; and

- How the respondent's ability to prepare for natural hazards in the future may be affected by the impact(s) of COVID-19 on their business.

\subsection{Attitudes Section}

This section asks the respondent to consider future plans for their SME in the context of COVID19 response, as well as short-, medium-, and longer-term concerns that may combine with COVID-19 impacts to create a complex event currently and into the future. For each of the concerns the respondent is asked to indicate: (1) their level of concern about the potential occurrence and (2) whether they or the SME at-large has implemented steps to reduce the business risks that are/would be related to the specific concern. The respondent is asked to consider the following type of events:

- Natural hazards / weather events and potential impacts of these events

- Market or financial volatility (e.g., supply chain disruption, operational issues)

- Subsequent wave of COVID-19 associated restrictions

- Other public health issues (e.g., flu season)

- Workforce issues (e.g., workforce safety, workforce reduction, absenteeism, retaining/rehiring staff consumer-side issues

- Consumer-side issues (e.g., preferences for online shopping, reductions in foot traffic, low holiday season sales)

Furthermore, the respondent was asked whether they feel that they have the resources needed to protect their SME against the identified risks and what resources, information, or support they feel they need. Finally, the respondent is asked to indicate the amount of time they think that will pass before the business returns to its pre-COVID-19 conditions (e.g., operational level), if ever.

\subsection{Business Information Section}

This section asks the respondent to provide more detailed information about the SME for which they have responded to the survey. For first time respondents as a part of Wave 2B respondents are asked to indicate the business sector, founding year, geographic location, and ownership structure. Respondents in Wave 2A and 2B are asked about their SME's typical monthly revenue pre-COVID-19 and relative revenue changes in the last month. Respondents are also asked to indicate what percentage of their current monthly expenses goes towards payments for things that no longer generate (direct) revenue, such as indoor dining space that cannot be used or office space that is not currently occupied. 
Respondents are asked to indicate ownership structure and their self-described race and ethnicity. Finally, the respondent is asked to indicate whether their SME employs anyone who identifies as disabled.

Six attitudinal questions are posed about COVID-19 and its relative impact on the SME, asking for levels of agreement.

- COVID-19 did not impact my business in any significant manner

- COVID-19 posed the greatest risk yet to my organization's survival

- The impacts of COVID-19 will leave my organization unable to cope with a natural disaster, should one occur, in the next year

- I am not concerned about a second wave of COVID-19 and the potential effects on my organization

- Stress on my business from COVID-19 has created increased stress in my home life

- Stress in my home life from COVID-19 has created increased stress for my business

\subsection{Closing Section}

The closing section of the survey asks whether the respondent would like to be considered for follow-up on their responses and/or be provided with a summary report of responses to the survey. Finally, the respondent is asked to provide any additional information of which they would like the survey team to be aware.

\subsection{Survey Approvals}

The final survey instrument went through the review process for the Paperwork Reduction Act (PRA) (1995. Pub. L. No. 104-13, 109 Stat 163) under the NIST Generic Clearance for Community Resilience Data Collections FW: Renewal of OMB Control \#0693-0078. The purpose of this review is to: "ensure the greatest possible public benefit from and maximize the utility of information created, collected, maintained, used, shared, and disseminated by or for the Federal Government; and to "improve the quality and use of Federal information to strengthen decision making, accountability, and openness in Government and society."

The data collection instruments and data collection methodologies for both Wave 2A and Wave 2B were also approved by the Institutional Review Board (IRB) at NIST, which oversees human subjects research.

The relevant PRA and IRB approvals are available upon request. 


\section{Summary and Future Efforts}

\subsection{Current Status}

At the time of writing, over a year has passed since the March 13, 2020 Federal Emergency Declaration concerning COVID-19. SME operators and those for whom SMEs provide employment and services in the larger community continue to face challenges related to COVID19 restrictions and decreases and/or changes in consumption patterns across a number of sectors. The US Congress has approved several stimulus and relief packages, with businesses receiving over \$ 700 billion in forgivable loans between March 2020 and March 2021 (US Chamber of Commerce, 2021). Mitigating health concerns is key to economic recovery (Chetty et al. 2020); as of writing, over 108 million people had received at least one vaccine dose, with over 63 million reported to be fully vaccinated. ${ }^{4}$ Moreover, many states and local jurisdictions have begun to loosen restrictions impacting SMEs business practices (e.g., opening hours and status) (KFF, 2021).

Many SME operators are dealing with impacts from and recovery towards complex events arising from natural hazards that occurred in 2020 - in many cases more than one natural hazard - during COVID-19. Furthermore, some SME operators and their communities are dealing with additional stressors from ongoing recovery from past natural hazards (pre-COVID19) and social vulnerabilities that are known to amplify impacts of other acute and chronic impacts.

There are indications that the COVID-19 transmission and direct impact period may start to subside, and a period of recovery will begin within the coming months; however, at the time of writing there is some fear of a spring surge in COVID-19 cases as the COVID-19 variants continue to spread quickly (White House, 2021). Public health guidance indicates that required limitations on many SMEs are rolling back at state and local levels (KFF, 2021). It is unclear the speed at which and the extent to which consumers and employees will return to pre-pandemic social norms in terms of interactions with SME services and goods offered. Remes et al. (2021) note that consumer spending, a major source of economic activity, will be robust, but there are lasting changes to consumer spending patterns.

The survey instruments presented in this DCI continue to help us understand SME-level planning for complex events across sectors and in the context of past experience and vulnerability profiles. Furthermore, elements of the survey may apply to both for-profit and non-profit enterprises in other data collections. As the researchers undertake the next phase of the SME Complex Event Resilience data collection effort focused around COVID-19 effects, the potential for complex events to occur from natural disasters is considerable. The 2021 hurricane season begins on June 1,2021 and it is expected to be another season of weather extremes, punctuated by a large number of natural hazards (WMO, 2021).

SMEs are inextricably linked to the communities in which they exist through provision of necessary goods and services, but they often depend upon customers and suppliers from the

4 CDC (2021). COVID-19 Vaccinations in the United States. https://covid.cdc.gov/covid-datatracker/\#vaccinations. Accessed: April 6, 2021. 
surrounding community. It is anticipated that lessons learned from this second wave of data collection and subsequent data collections will assist federal partners and other entities in providing new knowledge about complex events, which might assist them in providing guidance to SMEs on: 1. mitigation planning for natural disasters during the pandemic and 2. disaster readiness strategies to cope with the disruptions from the pandemic. Initial findings from the Wave 2A survey effort are available in Helgeson et al. (2021a).

Furthermore, the novel circumstances around the COVID-19 pandemic may provide additional insight into how SME operators make mitigation, adaptation, and coping decisions. The use of longitudinal data collection and analysis also allows us to attempt to understand circumstances, especially vulnerabilities, that make it challenging for SME operators to recovery fully, plan for future natural hazards, and in some cases reasons that an SME may close. The panel data obtained through these two waves of data collection provide critical baseline data and trajectory information related to impact and recovery that is needed to fully understand resilience trajectories.

\section{2. $\quad$ Future Research Plans}

In subsequent panel data collection efforts, the researchers plan to increase focus on SME recovery from COVID-19 and complex events. A focus on understanding the trade-offs and synergies across assets and resources of the SME (see Figure 4) during recovery and in planning for future disasters and complex events may help address SME vulnerabilities in development of PIPs.

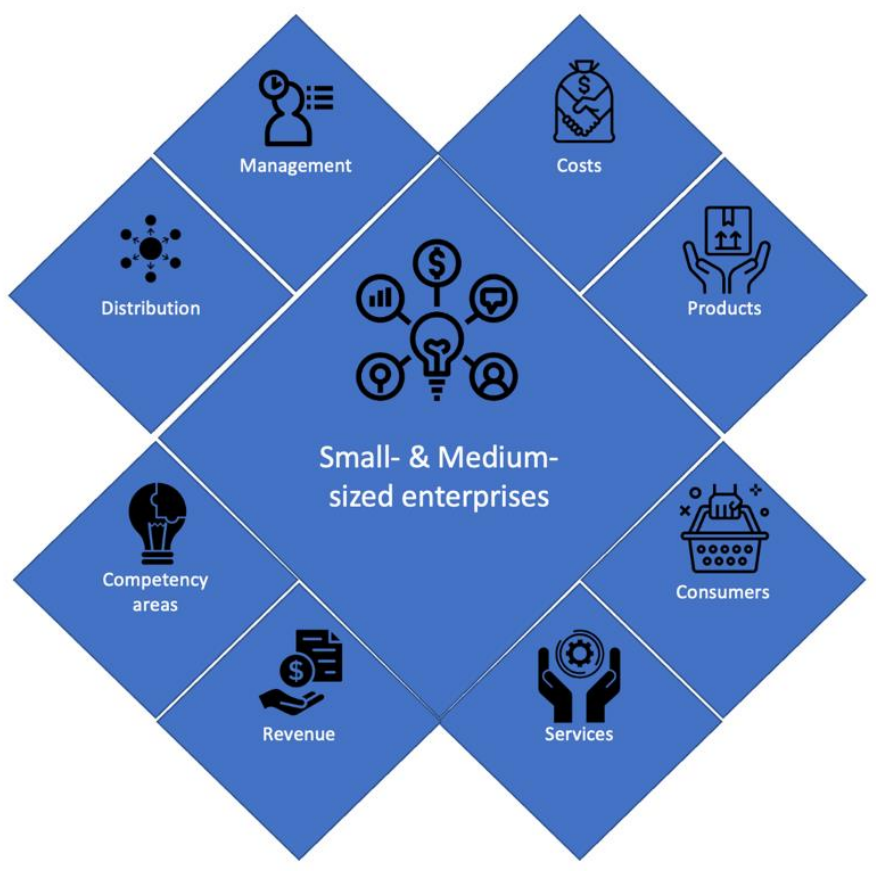

Figure 4. Categories of relevance to SME operation and recovery status. 
Accordingly, the researchers plan to synthesize qualitative and quantitative data collection and data analysis techniques to more elaborately study SME operators' organizational knowledge about business interruption and recovery and in planning for future disasters and complex events. In particular, (i) how SME operators' knowledge about mitigation, adaptation, and coping strategies and decisions is influenced by circumstances like being socially vulnerable and having been impacted by natural disasters; (ii) how this knowledge differs across business sectors, geographic locations, and ownership structure; and finally (iii) to what extent it enables SME operators to identify trade-offs and synergies across assets and resources of the SME during recovery.

By employing approaches like semi-quantitative mental modeling and cognitive mapping techniques (Aminpour et al., 2021; Halbrendt et al., 2014), the researchers plan to collect and analyze the SMEs' organizational knowledge. Mental models consist of beliefs and subjective knowledge that are constructed as individuals (e.g., SME operators) observe, interact with, and experience the world around them and concurrently develop internal representations to understand and predict how it functions (Mohammed and Dumville, 200; Gray et al. 2014; Johnson-Laird 1983). As such, they synthesize knowledge that is acquired through experiential, social, and formal learning.

SME operators' mental models about business interruption and recovery regarding disasters and complex events will be collected through cognitive mapping techniques (Aminpour et al., 2020; Gray et al., 2014). Cognitive maps are graph structures for representing concepts (nodes) and their causal relationships (edges) that provide a semi-quantitative tool for eliciting and analyzing personal and tacit knowledge, perceptions, and causal reasoning (Kosko, 1986; Ford and Sterman, 1998). By applying methods from network science to the analysis of cognitive maps, and by adopting a complex systems perspective, the researchers can more effectively study how trade-offs, synergies, feedback loops, and other important forms of complexities associated with SME resilience are perceived by SME operators facing concurrent and compound events (Hamilton et al., 2019; Levy et al., 2018).

In addition, eliciting and analyzing cognitive maps allows the researchers to explore the potentials for growing the SME operators' organizational knowledge through the application of "collective intelligence" approaches (Aminpour et al., 2021; Norström et al., 2020)exchanging, integrating, and co-producing knowledge resources from across the organizations and communities of practice which allows SME operators to access knowledge that span beyond the organization's borders and could be used to enhance the performance of the SME with regard to complex event resilience. 


\section{References}

Agility Recovery. (2019). Disaster Preparedness: Plan and Prepare for Hurricanes (pp. 1-4). Agility Recovery. http://www.agilityrecovery.com/assets/SBA/hurricaneprepsba.pdf

Aminpour, P., S.A. Gray, A. Singer, S.B. Scyphers, A.J. Jetter, R. Jordan, R. Murphy, and J.H. Grabowski. (2021). The diversity bonus in pooling local knowledge about complex problems. Proceedings of the National Academy of Sciences, 118(5).

Aminpour, P., S.A. Gray, A.J. Jetter, J.E. Introne, A. Singer, and R. Arlinghaus. (2020). Wisdom of stakeholder crowds in complex social-ecological systems. Nature Sustainability, 3(3), 191-199.

Augier, M. and D. J. Teece. (2009). Dynamic Capabilities and the Role of Managers in Business Strategy and Economic Performance. Organization Science, 20(2), 410- 421. https://doi.org/10.1287/orsc.1090.0424

Bartik, A.W. , M. Bertrand, Z. Cullen, E.L. Glaeser, M. Luca, and C. Stanton. (2020). "The impact of COVID-19 on small business outcomes and expectations." PNAS July 28, 2020117 (30) 17656-17666; https://doi.org/10.1073/pnas.2006991117

Bethlehem, J. (2010). Selection bias in web surveys. International Statistical Review, 78(2), 161-188. https://doi.org/10.1111/j.1751-5823.2010.00112.x

Buffington, Catherine, Carrie Dennis, Emin Dinlersoz, Lucia Foster, and Shawn Klimek. 2020. "Measuring the Effect of COVID-19 on U.S. Small Businesses: The Small Business Pulse Survey," Center for Economic Studies Working Paper, 20-16.

Burton, D. C., Confield, E., Gasner, M. R., \& Weisfuse, I. B. (2011). A qualitative study of pandemic influenza preparedness among small and medium-sized businesses in New York City. 14.

Centers for Disease Control and Prevention. (2017). Get your Workplace Ready for Pandemic Flu, (p. 16). https://www.cdc.gov/nonpharmaceutical-interventions/pdf/grpanflu-work-set.pdf

Centers for Disease Control and Prevention. (2017). Get your Workplace Ready for Pandemic Flu, (p. 16). https://www.cdc.gov/nonpharmaceutical-interventions/pdf/grpanflu-work-set.pdf

Cardona, O.D., M.K. van Aalst, J. Birkmann, M. Fordham, G. McGregor, R. Perez, R.S. Pulwarty, E.L.F. Schipper, and B.T. Sinh, 2012: Determinants of risk: exposure and vulnerability. In: Managing the Risks of Extreme Events and Disasters to Advance Climate Change Adaptation [Field, C.B., V. Barros, T.F. Stocker, D. Qin, D.J. Dokken, K.L. Ebi, M.D. Mastrandrea, K.J. Mach, G.-K. Plattner, S.K. Allen, M. Tignor, and P.M. Midgley (eds.)]. A Special Report of Working Groups I and II of the Intergovernmental Panel on 
Climate Change (IPCC). Cambridge University Press, Cambridge, UK, and New York, NY, USA, pp. 65-108.

Cannon, T., J. Twigg, and J. Rowell, 2003. Social Vulnerability, Sustainable Livelihoods and Disasters. London: Conflict and Humanitarian Assistance Department and Sustainable Livelihoods Support Office, Department for International Development.

CDC Foundation and Well Being Trust. (2020). "Thriving Together: A Springboard for Equitable Recovery and Resilience in Communities Across America.” Bobby Milstein, Monte Roulier, Christopher Kelleher, Elizabeth Hartig, and Stacy Wegley (editors). July 4, 2020. https://thriving.us/wp-content/uploads/2020/07/Springboard-Full-Content-ForPrint-.pdf

Deng, Y., D. S. Hillygus, J.P. Reiter, Y. Si, S. Zheng. (2013). "Handling Attrition in Longitudinal Studies: The Case for Refreshment Samples." Statist. Sci. 28 (2) 238 256, May 2013. https://doi.org/10.1214/13-STS414

Dewan A.M. 2013. "Hazards, Risk, and Vulnerability. In: Floods in a Megacity." Springer Geography. Springer, Dordrecht. https://doi.org/10.1007/978-94-007-58759_2

DuGoff, E. H., M. Schuler, and E.A. Stuart. (2014), "Generalizing Observational Study Results: Applying Propensity Score Methods to Complex Surveys," Health Service Research, 49, 284-303.

Ford, D. N., and Sterman, J. D. (1998). Expert knowledge elicitation to improve formal and mental models. System Dynamics Review: The Journal of the System Dynamics Society, 14(4), 309-340.

Gray, S. A., Zanre, E., and Gray, S. R. (2014). Fuzzy cognitive maps as representations of mental models and group beliefs. In Fuzzy cognitive maps for applied sciences and engineering (pp. 29-48). Springer, Berlin, Heidelberg.

Grinyer, P. H., and Spender, J.-C. (1979). Recipes, Crises, and Adaptation in Mature Businesses. International Studies of Management \& Organization, 9(3), 113-133.

Halbrendt, J., Gray, S. A., Crow, S., Radovich, T., Kimura, A. H., \& Tamang, B. B. (2014). Differences in farmer and expert beliefs and the perceived impacts of conservation agriculture. Global Environmental Change, 28, 50-62.

Handmer, J. and S. Dovers. "A Typology of Resilience: Rethinking Institutions for Sustainable Development." The Earthscan Reader on Adaptation to Climate Change, Earthscan, London (2009), pp. 187-210

Helgeson, J., J. F. Fung, Y. Zhang, A. Roa Henriquez, A. Zycherman, C. Nierenberg, D. 
Butry, D. Ramkissoon (2020a). Complex Event Resilience of Small- and Medium-Sized Enterprises: Natural Disaster Planning During the COVID-19 Pandemic. NIST SP 1258, Gaithersburg, MD. doi: 106028/NIST.SP1258

Helgeson, J. , J. F. Fung, A. Roa Henriquez, A. Zycherman, C. Nierenberg, Y. Zhang, D. Butry, D. Ramkissoon. (2020b). "Respondent Summary Report Business Survey: COVID-19 Impacts and Recovery in the Context of Complex Events." Special Publication (NIST SP), National Institute of Standards and Technology, Gaithersburg, MD, [online], https://doi.org/10.6028/NIST.SP.1264

Helgeson, J., J. F. Fung, Y. Zhang, A. Roa Henriquez, A. Zycherman, C. Nierenberg, D. Butry, D. Ramkissoon (2020c). Eliciting lessons from small- and medium sized enterprises (SMEs) for natural disaster resilience planning and recovery during the COVID-19 pandemic: SME Complex Event Resilience. NIST DCI 002, Gaithersburg, MD. doi: 106028/NIST.DCI002

Helgeson, J., J. Fung, and A. Roa-Henriquez. (2021a). "Rationally bounded in a storm of complex events: small businesses facing natural hazard resilience during a pandemic." Journal of Behavioral Economics for Policy. Vol. 4, COVID-19 Special Issue 3, 55-65. https://sabeconomics.org/wordpress/wp-content/uploads/JBEP-4-S3-4.pdf

Helgeson, J. (2021b). "Longitudinal Study of Complex Event Resilience of Small- and MediumSized

Enterprises: Natural Disaster Planning and Recovery During the COVID-19 Pandemic (Wave 2)." Special Publication (NIST SP), National Institute of Standards and Technology, Gaithersburg, MD. https://doi.org/10.6028/NIST.SP.1267.

Huddleston Jr., T. (2020, March 23). How small business owners are coping with COVID-19 pandemic: 'It was my civic duty to be a part of the solution'. Retrieved September 10, 2020, from https://www.cnbc.com/2020/03/23/how-small-businesses-across-usarecoping-with-covid-19-pandemic.html

Johnson-Laird, P. N. (1983). Mental models: Towards a cognitive science of language, inference, and consciousness (No. 6). Harvard University Press.

Karl, T. and W. Koss. 1984. "Regional and National Monthly, Seasonal, and Annual Temperature Weighted by Area, 1895-1983." Historical Climatology Series 4-3, National Climatic Data Center, Asheville, NC, 38 pp.

KFF. (2021). "State Social Distancing Actions, as of April 5, 2021." https://www.kff.org/report-section/state-covid-19-data-and-policy-actions-policyactions/\#socialdistancing. Accessed April 10, 2021.

Kosko, B. (1986). Fuzzy cognitive maps. International journal of man-machine studies, 24(1), 65-75. 
Kozel, V., P. Fallavier and R. Badiani (2008): "Risk and Vulnerability Analysis in World Bank Analytic Work - FY2000-FY2007”, World Bank Discussion Paper, No. 0812.

Lavell, A., M. Oppenheimer, C. Diop, J. Hess, R. Lempert, J. Li, R. Muir-Wood, and S. Myeong, 2012: Climate change: new dimensions in disaster risk, exposure, vulnerability, and resilience. In: Managing the Risks of Extreme Events and Disasters to Advance Climate Change Adaptation [Field, C.B., V. Barros, T.F. Stocker, D. Qin, D.J. Dokken, K.L. Ebi, M.D. Mastrandrea, K.J. Mach, G.-K. Plattner, S.K. Allen, M. Tignor, and P.M. Midgley (eds.)]. A Special Report of Working Groups I and II of the Intergovernmental Panel on Climate Change (IPCC). Cambridge University Press, Cambridge, UK, and New York, NY, USA, pp. 25-64.

Lavrakas, P. J. (2008). Encyclopedia of Survey Research Methods. SAGE Publications

Levenson, M. (2020, March 20). Anheuser-Busch and Distilleries Race to Make Hand Sanitizer Amid Coronavirus Pandemic. Retrieved September 10, 2020, from https://www.nytimes.com/2020/03/19/us/distilleries-virus-hand-sanitizer.html

Levy, M. A., Lubell, M. N., \& McRoberts, N. (2018). The structure of mental models of sustainable agriculture. Nature Sustainability, 1(8), 413-420.

Marques, J. (2003). Social safety net assessments from Central America: cross-country review of principal findings (Social Protection Discussion Paper No. SP 0316). Washington, DC: Social Protection Unit, Human Development Network, The World Bank.

Mohammed, S., and Dumville, B. C. (2001). Team mental models in a team knowledge framework: Expanding theory and measurement across disciplinary boundaries. Journal of Organizational Behavior: The International Journal of Industrial, Occupational and Organizational Psychology and Behavior, 22(2), 89-106.

National Center for the Middle Market NCMM (2021, January). COVID-19 and the MIDDLE market: 4q 2020. https://www.middlemarketcenter.org/middle-marketresearch-reports-full-research/covid-19-and-middle-market-companies-4q-2020 Accessed April 01, 2021.

NOAA National Centers for Environmental Information (NCEI) U.S. Billion-Dollar Weather and Climate Disasters (2021). https://www.ncdc.noaa.gov/billions/, DOI: 10.25921/stkw$7 \mathrm{w} 73$.

Norström, A. V., Cvitanovic, C., Löf, M. F., West, S., Wyborn, C., Balvanera, P., Bednarek, A., Bennett, E., Biggs, R., de Bremond, A., Campbell, J., Carpenter, S., Folke, C., Fulton, E., Gaffney, O. , Gelcich, S., Jouffray, J., Leach, M., Le Tissier, M., Martin-Lopez, B., Louder, E., Loutre, M., Meadow, A., Nagendra, H., Payne, D., Peterson, G., Reyers, B., Scholes, R., Speranza, C., Spierenburg, M., Stafford-Smith, M., Tengö, M., van der Hel, 
S., van Putten, I. and Österblom, H. (2020). Principles for knowledge co-production in sustainability research. Nature Sustainability, 3(3), 182-190.

Pew Research Center (2021a). Demographics of internet and home broadband usage in the United States. https://www.pewresearch.org/internet/fact-sheet/internet-broadband/\#whois-smartphone-dependent Accessed April 12, 2021.

Pew Research Center (2021b). Mobile Fact Sheet. https://www.pewresearch.org/internet/fact-sheet/mobile/ Accessed April 20, 2021.

Phillips, C.A., A. Caldas, R. Cleetus, K. A. Dahl, J. Declet-Barreto, R. Licker, L.D. Merner, J. P. Ortiz-Partida, A.L. Phelan, E. Spanger-Siegfried, S. Talati, C.H. Trisos and C.J. Carlson. (2020). "Compound climate risks in the COVID-19 pandemic." Nat. Clim. Chang. 10, 586-588 https://doi.org/10.1038/s41558-020-0804-2.

Remes, J., J. Manyika, S. Smit, S. Kohil, V. Fabius, S. Dixon-Fyle, and A. Nakaluzhnyi. 2021. "The consumer demand recovery and lasting effects of COVID-19." https://www.mckinsey.com/industries/consumer-packaged-goods/our-insights/theconsumer-demand-recovery-and-lasting-effects-of-covid-19 Accessed April 10, 2021.

Runyan, R. C. (2006). Small Business in the Face of Crisis: Identifying Barriers to Recovery from a Natural Disaster. Journal of Contingencies and Crisis Management, 14(1), 12-26. https://doi.org/10.1111/j.1468-5973.2006.00477.

Sadiq, A. A. (2011). Adoption of hazard adjustments by large and small organizations: who is doing the talking and who is doing the walking?. Risk, Hazards \& Crisis in Public Policy, 2(3), 1-17.

Sarker, M. N. I., Q. Cao, M. Wu, M.A. Hossin, G.M. Alam, and R.C. Shouse. (2019). Vulnerability and livelihood resilience in the face of natural disaster : A critical conceptual review. Applied Ecology and Environmental Research, 17(6): 12769-85. Available: https://doi.org/10.15666/aeer/1706_1276912785

Schonlau, M. A. van Soest, A. Kapteyn, M. Couper. "Selection Bias in Web Surveys and the Use of Propensity Scores." Sociological Methods \& Research. 2009;37(3):291-318. doi: $\underline{10.1177 / 0049124108327128}$

Schindehutte, M. and M.H. Morris. (2001). Understanding strategic adaptation in small firms. International Journal of Entrepreneurial Behavior \& Research, 7(3), 84107. https://doi.org/10.1108/EUM0000000005532.

Swiss Re. 2020. Swiss Re Institute estimates USD 83 billion global insured catastrophe losses in 2020, the fifth costliest on record. https://www.swissre.com/media/newsreleases/nr-20201215-sigma-full-year-2020-preliminary-natcat-loss-estimates.html. Accessed Feb. 2, 2021.

Tanner, T., D. Lewis, D. Wrathall, R. Bronen, N. Cradock-Henry, S. Huq, C. Lawless, R. 
Nawrotzk, V. Prasad, M.A. Rahman, R. Alaniz, K. King, K. McNamara, M.

Nadiruzzaman, S. Henly-Shepard, F. Thomalla. (2015): Livelihood resilience in the face of climate change. - Nature Climate Change 5(1): 23-26.

https://doi.org/10.1038/nclimate2431.

Torres, A. P., M. I. Marshall, and S. Sydnor. (2019, June 1). Does social capital pay off? The case of small business resilience after Hurricane Katrina. Journal of Contingencies and Crisis Management. https://doi.org/10.1111/1468-5973.12248

United Nations. (2013). United Nations Plan of Action on Disaster Risk Reduction for Resilience. https://www.preventionweb.net/files/33703_actionplanweb14.06cs1.pdf. Accessed March 15, 2021.

United States Census Bureau (2018, August 20). Census Regions and Divisions of the United States. Retrieved March 31, 2021, from https://www2.census.gov/geo/pdfs/mapsdata/maps/reference/us_regdiv.pdf

Watkins, R. E., F.C. Cooke, R.J. Donovan, C.R. MacIntyre, R. Itzwerth, and A.J. Plant. (2008). Tackle the Problem When It Gets Here: Pandemic Preparedness Among Small and Medium Businesses. Qualitative Health Research, 18(7), 902-912. https://doi.org/10.1177/1049732308318032

Watkins, R. J., D. J. Barnett, and J.M. Links. (2008). Corporate Preparedness for Pandemic Influenza: A Survey of Pharmaceutical and Biotechnology Companies in Montgomery County, Maryland. Biosecurity and Bioterrorism: Biodefense Strategy, Practice, and Science, 6(3), 219-226. https://doi.org/10.1089/bsp.2008.0024

Wedawatta, G. and B. Ingirige (2012). "Resilience and adaptation of small and medium-sized enterprises to flood risk." Disaster Prevention and Management 21(4):474-488. https://doi.org/10.1108/09653561211256170

White House. (2021). "Press Briefing by White House COVID-19 Response Team and Public Health Officials - MARCH 22, 2021.” https://www.whitehouse.gov/briefingroom/press-briefings/2021/03/22/press-briefing-by-white-house-covid-19-response-teamand-public-health-officials-18/ Accessed April 10, 2021.

World Meteorological Organization. (2021). "WMO Hurricane Committee retires tropical cyclone names and ends the use of Greek alphabet. https://public.wmo.int/en/media/pressrelease/wmo-hurricane-committee-retires-tropical-cyclone-names-and-ends-use-of-greek Accessed April 10, 2021. 


\section{Appendix A: Invitation / Front Matter - Wave 2A}

\section{Small- and Medium-Sized Business Complex Event COVID-19 Survey (Wave 2)}

Dear

Thank you for responding to our survey during Summer 2020. The information learned was invaluable and was developed into reports and suggested actions for businesses like yours and the institutions that serve them.

We understand that the COVID-19 pandemic may still be affecting your business. Your continued participation is critical for the development of guidance on how businesses like yours are adapting to the current circumstances.

Please spend a few minutes filling out this follow-up survey.

https://www.surveymonkey.com/ז

We ask for no sensitive information and we will not identify you or your business. If your business has more than one location, please answer for only one location. We'd like to learn about practices taken that have helped reduce the impact of COVID-19, especially in the face of future hazard events.

You may skip any questions or exit the survey at any time.

This survey should take less than 15 minutes to complete. You may opt to receive aggregate results of the survey (at the end).

Both your perspective and time are exceptionally invaluable, especially during these uncertain times. Our efforts will be greatly enhanced if you choose to continue to participate.

Thank you for your time and participation.

A brief report from the first survey is available here: https://nvipubs.nist.gov/nistpubs/SpecialPublications/NIST.SP.1259.pdf

Jennifer

SMEResearch@nist.gov

Click the button below to start the survey. Thank you for your participation!

Begin Survey 


\section{Appendix B: Invitation / Front Matter - Wave 2B}

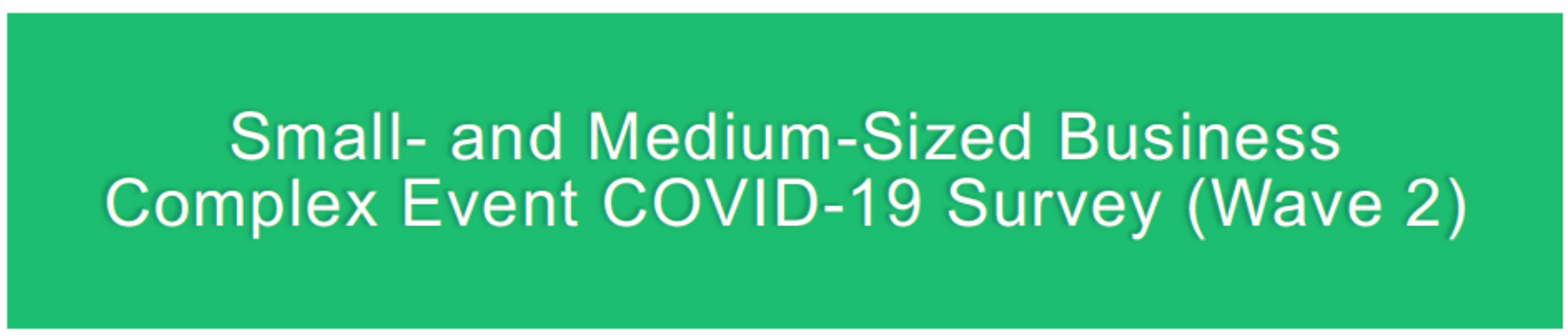

Dear

We understand that the COVID-19 pandemic is disrupting your business. We hope to learn how businesses like yours are adapting to the circumstances and how this may or may not be connected to broader weather-related stressors your business may face. Both your perspective and time are exceptionally precious, especially during these uncertain times. Our efforts will be greatly enhanced if you can spend a few minutes filling out this survey.

https://www.surveymonkey.com/r/Preview?

$\mathrm{sm}=\mathrm{qCAFNC}$

We ask for no sensitive information and we will not identify you or your business. If your business has more than one location, please answer for only one location. The purpose of this survey is to understand what support businesses like yours need and to communicate those to those who may be able to provide assistance. We'd like to learn about practices taken that have helped reduce the impact of COVID-19, especially in the face of future hazard events. If you feel uncomfortable answering any of the questions, you can skip them, or exit the survey at any time. This survey should take less than 15 minutes to complete. You may opt to receive the aggregate results of the survey (at the end).

Thank you for your time and participation.

If you prefer to answer in Spanish, please use this link: https://es.surveymonkey.com/r/SpanishSME Jennifer

Applied Economics Office, National Institute of Standards and Technology, U.S. Dept. of Commerce SMEResearch@nist.gov

Click the button below to start the survey. Thank you for your participation!

Survey in English

Encuesta en español

Please do not forward this email as its survey link is unique to you. 


\section{Appendix C: Wave 2A Survey (English)}

\section{Dept. of Commerce Small- and Medium-Sized Business Complex Event COVID-19 Survey}

\section{OMB Control \# 0693-0078}

Expiration 07/31/2022

We understand that the COVID-19 pandemic may be disrupting your business. We hope to learn how businesses like yours are adapting to the circumstances and how this may or may not be connected to broader weather-related stressors your business may face.

Both your perspective and time are exceptionally precious, especially during these uncertain times.

Our efforts will be greatly enhanced if you can spend a few minutes filling out this survey. We ask for no sensitive information and we will not identify you or your business. If your business has more than one location, please answer for only one location.

The purpose of this survey is to understand what support businesses like yours need and to communicate those to those who may be able to provide assistance. We'd like to learn about practices taken that have helped reduce the impact of COVID-19, especially in the face of future hazard events.

If you feel uncomfortable answering any of the questions, you can skip them, or exit the survey at any time.

This survey should take less than 15 minutes to complete. You may opt to receive aggregate results of the survey (at the end).

Thank you for your time and participation.

Jennifer

SMEResearch@nist.gov 
Dept. of Commerce Small- and Medium-Sized Business Complex Event COVID-19 Survey

* What is the current status of your business?

Fully open with the same products and services as pre-COVID-19

Open, but with fewer or different products or services

Temporarily closed, but plan to reopen

Permanently closed

[if "closed"]

Approximately when did your business close?

Date / Time

Date

MM/DD/YYYY

Was the business closure related to the COVID-19 pandemic?

Yes

No Ot

Other

Please explain

tores

Did the business experience other issues that contributed to the closure? Please select all that apply.

Natural hazard or extreme weather impacts

Market/Financial volatility (e.g., lower productivity, supply chain disruption, operational issues)

Public health concerns / illness (e.g., ability to keep customers or yourself safe)

Workforce issues (e.g., workforce safety, rehiring/replacing/retaining workforce)
Consumer-side issues (e.g., preferences for online shopping, reduction in foot traffic)

Personal reasons (e.g. family responsibilities, personal financial hardships, retirement)

Other

Please provide details 
Did the business implement any of the following before permanently closing? Please select all that apply

$\square$ Laid off some of the workforce
$\square$ Reduced salaries
$\square$ Sold some of the business' assets
$\square$ Increased debt/borrowing
Please provide details


Do you expect that the business will open again in the future?

(j) Yes

No

Maybe / Unsure

Please provide details 


\section{Dept. of Commerce Small- and Medium-Sized Business Complex Event COVID-19 Survey}

When was your business allowed to operate in your jurisdiction after the start of the COVID-19 pandemic? (an approximate date is fine) Please respond with a date after March 13, 2020. If your business never closed, please select March 13, 2020.

Date

Date

MM/DD/YYYY

How would you describe the impact you are currently experiencing from COVID-19?

It is NOT impacting my business

It is starting to impact my business

It is continuing to impact my business
The impact is on the decline

The impact is over

It has had a POSITIVE impact on my business

How has the COVID-19 pandemic impacted the continuity/stability of your day-to-day operations? Please answer if an action occurred during ANY or ALL of the time periods March 13-July 31 and August 1-Present.

March 13-July 31, 2020

Remained fully open

Reduced days/hours

Closed to the public

All staff working from

home

Some staff working from

home

Services added

Increased e-commerce

Please provide details
August 1, 2020-Present

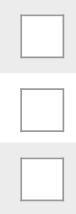


How has the COVID-19 pandemic impacted the operation of your business? Please answer if an action occurred during ANY or ALL of the time periods March 13-July 31 and August 1-Present.

March 13-July 31, 2020

August 1, 2020-Present

\section{Stopped operation due}

to external mandate

Stopped operation due

to financial issue(s)

Decrease in revenue

Increase in revenue

Problems with supply

chain/receiving or

shipping inventory

Issues with delivery of products to customers

Decrease in customers

Increase in customers

Please provide details 
What are the most important factors that influenced the choice of whether or not to resume operations or to continue operations if they never ceased? (Please select no more than 5)

Local business opening guidance

Employee safety

Change in customers

Disruption to supply/inventory delivery

University and school opened/closed

Nearby businesses opened/closed

Local government information/suggestion

Level of concern about infection (self, employees, customers, and/or suppliers)

Availability of personal protective equipment and/or cleaning supplies

Absenteeism

Staff's desire to return to work

Media coverage

Business margins

Costs to comply with COVID-19 requirements (e.g., installation of plexiglass dividers)

Vaccine approval/ rollout for COVID-19

December COVID-19 Relief Bill

Does not apply to my business

Other (Please provide details) 
Since the start of the COVID-19 pandemic (March 13, 2020) has your business REQUESTED and/or RECEIVED any of the following financial assistance? (please check all that apply)

$\begin{array}{ll}\text { Requested } \quad \text { Received Received } & \text { NOT Red }\end{array}$

SBA Paycheck

Protection Program

(PPP)

SBA Economic Injury

Disaster Loans (EIDL)

Other Federal Programs

State and Local

Government

grants/loans

Banks

Personal liquidity

(savings)

Family, Friends, Crowd-

funding

Postponement in

payment (rent, utilities)

This business has not

sought financial

assistance from any

source

Unsure

Does not apply to my

business

Please provide details

Prons

Please describe anything your business has started or continues to do to address the COVID-19 pandemic. Please answer if your business took any action during ANY or ALL of the time periods.

March 13-July 31, 2020

August 1, 2020-Present

Changed products or services offered to consumers

Reduced number of people allowed within the business space

Offered contactless pick-

up or delivery

Increased e-commerce 
Curb-side pick-up made available

Renegotiated or gave-up

lease

Prioritized inventories to some customers

Reallocated products based on inventory levels

\section{Exchanged inventory} with another business (to fill a gap)

Increased staff

\section{Reduced staff}

Allowed employees

(some or all) to work remotely

\section{Negotiated longer}

payment terms for

suppliers so the

company can keep its

cash longer

\section{Collected money owed}

from customers as early

as possible

\section{Renegotiated current} and future prices with my suppliers
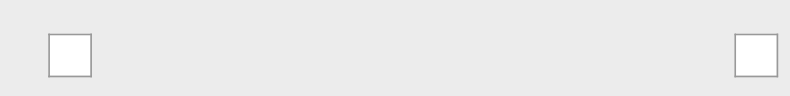

Exchanged resources or information with other organizations

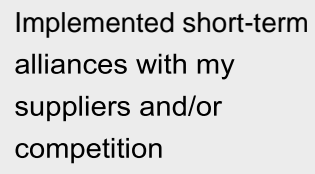

Other

Please provide details 
6.3. If you had the information and experience you have today, would you have made different choices for your business at the start of the COVID-19 pandemic?

Yes, definitely

Maybe

No, definitely not

Not sure

Please specify what you may have done differently. 


\section{Dept. of Commerce Small- and Medium-Sized Business Complex Event COVID-19 Survey}

The section asks you about risks from natural hazards and extreme weather. We are interested in your business' experience in the past and planning for the future.

What natural hazard(s) is/are of the greatest concern for your business' location? (select all that apply)

$\begin{array}{ll}\square \text { Coastal storms } & \square \text { Space weather } \\ \square \text { Drought/water scarcity } & \square \text { Tsunami } \\ \square \text { Earthquake } & \square \text { Wildfire } \\ \square \text { Extreme cold } & \square \text { Winter storms (snow, frozen rain) } \\ \square \text { Extreme heat/heat waves } & \square \text { Other } \\ \square \text { Flooding } & \square \text { None } \\ \square & \text { Hurricane } \\ \square & \text { Storm surge }\end{array}$

How many of these types of events have affected your business in the past 10 years? An estimate is fine. "Affected" means at least a one-day closure.

0

50

Did any of these natural hazard events occur at your location during the period March 13, 2020 to the present?

Yes, with severe negative impacts

Yes, with minor negative impacts

Yes, with no negative impacts

No

Unsure

Does not apply to my business 


\section{Dept. of Commerce Small- and Medium-Sized Business Complex Event COVID-19 Survey}

Was your business' response to this event impacted by COVID-19?

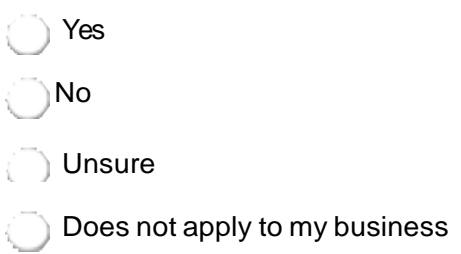

Please provide details

How did the event impact your business compared to similar events before COVID-19?

Greater impact than in the past

Similar significance to past experience(s)

Less significant than past experience(s)
First time such an event impacted my business

Does not apply to my business 


\section{Dept. of Commerce Small- and Medium-Sized Business Complex Event COVID-19 Survey}

6.4. Was the impact greater than in the past because of the nature of the natural hazard or extreme weather event (e.g., hurricane category or wildfire strength)?

No, COVID-19 increased the impact

Yes

Unsure

6.5. What type of actions has your business taken in the past (before COVID-19) to address natural hazards?

Floodproof building(s) - permanent (e.g., flood gate)

Floodproof building(s) - temporary (e.g., sand bags, boarding doors)

Secure a secondary storage location

Assess building to ensure construction meets building code standards

Perform risk assessment to identify business vulnerabilities (to specific hazards)

Adopt strategies to stay informed of weather watches and warnings (e.g., NOAA Weather Radio, commercial apps)

Assigned disaster responsibilities (i.e., emergency management function) to specific employees

Perform safety drills regularly (e.g., shelter-in-place, evacuations, telephone tree)

Develop a written emergency action plan/checklist

Back-up all important documents (digitally or stored at secondary location)Lift inventory and other supplies off the ground to prevent water exposure

Perform an insurance check-up to ensure adequate insurance coverage
Increase insurance coverage, if needed

Develop/update telework plans

Establish or increase remote/online sales capacity

Social media account use to provide operations information to the public (e.g., closings)

Minimize supply chain vulnerability through multiple source strategies

Develop a connection to local emergency management officials

Clear debris/dry vegetation away from structures

Back-up power generation

Maintain/tune-up equipment for debris/snow removal

Keeping an emergency fund ("rainy day" money on-hand)

None

Does not apply to my business

Other (please specify) 
6.6. Have actions taken by your business to prepare for natural disasters helped to address the impacts of COVID-19?

Yes (e.g., insurance purchases, teleworking, emergency supplies or finance)

No

Unsure

Please provide details

6.7. Do you plan to adopt any of the practices used during the COVID-19 pandemic in anticipation of future natural hazards? Yes

No

Unsure

Does not apply to my business

Please provide details

6.8. How has your ability to prepare for natural hazards in the future been affected by the impact of COVID-19 on your business?

It makes it significantly harder

It makes it somewhat easier

It makes it somewhat harder

It makes it significantly easier

It has not changed

Does not apply to my business 


\section{Dept. of Commerce Small- and Medium-Sized Business Complex Event COVID-19 Survey}

This section asks you about your business' future plans. 
Dept. of Commerce Small- and Medium-Sized Business Complex Event COVID-19 Survey

Do natural hazards / weather events and potential impacts of these events cause concern for your business?

C Yes

No

Unsure

Does not apply to my business 
Dept. of Commerce Small- and Medium-Sized Business Complex Event COVID-19 Survey

Have you implemented steps to reduce business risks related to natural hazard / weather events and potential impacts?

Yes, already implemented

Yes, in the process of implementation

Yes, planning to implement

No, but would like to learn more
No, do not plan to do so

No, I don't feel that there is anything I can do

C Unsure

Please provide details 


\section{Dept. of Commerce Small- and Medium-Sized Business Complex Event COVID-19 Survey}

Do market or financial volatility (e.g., supply chain disruption, operational issues) cause concern for your business?

Yes
No
Unsure
Does not apply to my business


Dept. of Commerce Small- and Medium-Sized Business Complex Event COVID-19 Survey

Have you implemented steps to reduce business risks related to market or financial volatility?

Yes, already implemented

Yes, in the process of implementation

Yes, planning to implement

No, but would like to learn more
No, do not plan to do so

No, I don't feel that there is anything I can do

( Unsure

Please provide details 


\section{Dept. of Commerce Small- and Medium-Sized Business Complex Event COVID-19 Survey}

Will a subsequent wave of COVID-19 associated restrictions cause concern for your business?
Yes
No
Unsure
Does not apply to my business 
Dept. of Commerce Small- and Medium-Sized Business Complex Event COVID-19 Survey 
Dept. of Commerce Small- and Medium-Sized Business Complex Event COVID-19 Survey

Have you implemented steps to reduce business risks related to a potential additional wave of COVID-19 associated restrictions?

Yes, already implemented

Yes, in the process of implementation

Yes, planning to implement

No, but would like to learn more
No, do not plan to do so

No, I don't feel that there is anything I can do

Unsure

Please provide details 


\section{Dept. of Commerce Small- and Medium-Sized Business Complex Event COVID-19 Survey}

Do other public health issues (e.g., flu season) cause concern for your business?

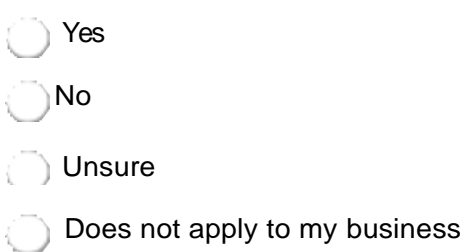


Dept. of Commerce Small- and Medium-Sized Business Complex Event COVID-19 Survey

Have you implemented steps to reduce business risks from other public health concerns?

Yes, already implemented

Yes, in the process of implementation

Yes, planning to implement

No, but would like to learn more
No, do not plan to do so

No, I don't feel that there is anything I can do

Unsure

Please provide details 
Dept. of Commerce Small- and Medium-Sized Business Complex Event COVID-19 Survey

Do workforce issues (e.g., workforce safety, workforce reduction, absenteeism, retaining/rehiring staff) cause concern for your business?

Yes

No

Unsure

Does not apply to my business 
Dept. of Commerce Small- and Medium-Sized Business Complex Event COVID-19 Survey

Have you implemented steps to reduce business risks from workforce concerns?

Yes, already implemented

Yes, in the process of implementation

Yes, planning to implement

No, but would like to learn more
No, do not plan to do so

No, I don't feel that there is anything I can do

( Unsure

Please provide details 


\section{Dept. of Commerce Small- and Medium-Sized Business Complex Event COVID-19 Survey}

Do consumer-side issues (e.g., preferences for online shopping, reductions in foot traffic, low holiday season sales) cause concern for your business?

Yes

No

Unsure

Does not apply to my business 
Dept. of Commerce Small- and Medium-Sized Business Complex Event COVID-19 Survey

Have you implemented steps to reduce business risks from consumer-side concerns?

Yes, already implemented

Yes, in the process of implementation

Yes, planning to implement

No, but would like to learn more
No, do not plan to do so

No, I don't feel that there is anything I can do

( Unsure

Please provide details 


\section{Dept. of Commerce Small- and Medium-Sized Business Complex Event COVID-19 Survey}

Do you feel that you have the resources needed to protect your business against the risks you just identified?

$$
\begin{aligned}
& \text { Yes } \\
& \text { No } \\
& \text { Unsure }
\end{aligned}
$$

What resources, information, or support do you feel you need to be better protected against the risks you identified?

How much time do you think will pass from TODAY until your business returns to its pre-COVID-19 conditions (e.g., operational level)?
Already there
1 month or less
2-3 months
4-6 months
6-12 months

12-18 months

More than 18 months

Unlikely to resume operations at that level

Unlikely to resume operations atall

Unsure

Please provide details

This section asks you to provide some information about your business and yourself.

\section{Which sector best describes your business?}

Construction

Manufacturing

Retail trade

Accommodation and Food Services

Wholesale trade

Transportation and Warehousing

Finance and Insurance

Information (e.g. radio, newspaper, television, telecommunications)

Real estate, rentals, and leasing

Other (please specify)
Professional, scientific, and technical services

Health and medical services

Arts, Entertainment, and Recreation

Food processing, agriculture

Natural resource management

Fuel production

Fishing/aquaculture

Tourism 
How many full-time AND part-time individuals did your business employ at this location at this time last year?
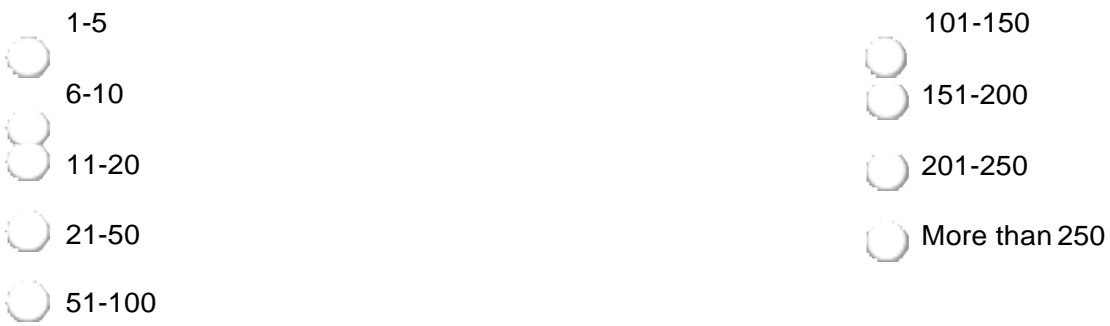

Compared to this time last year, what is the approximate percent CHANGE in employees at this business? (Please include all full-time AND part-time individuals)? A negative change means fewer employees.
$-100 \%$
no change
$+100 \%$

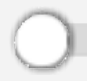

Before COVID-19 what was the typical monthly revenue for your business (not including any financial assistance or loans)? Please use this time in 2019 for reference.
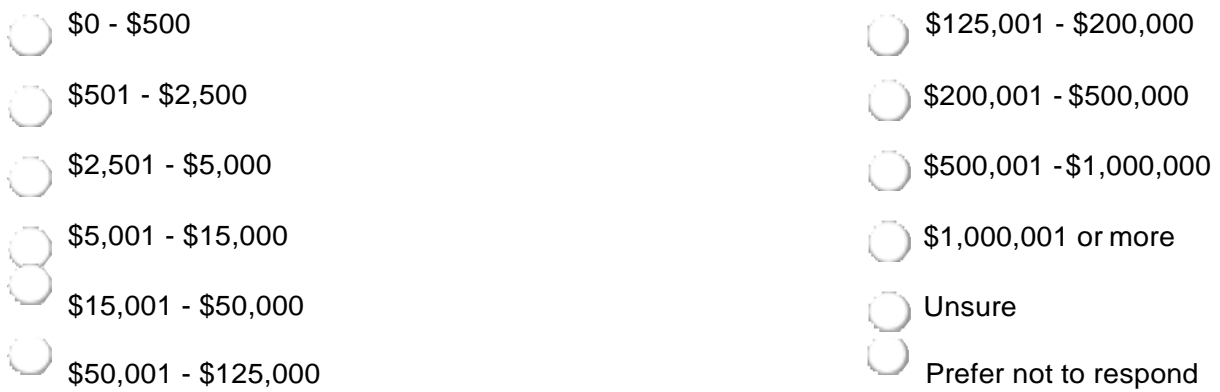

What percent change did you see in monthly revenue due to COVID-19 last month relative to that time last year?

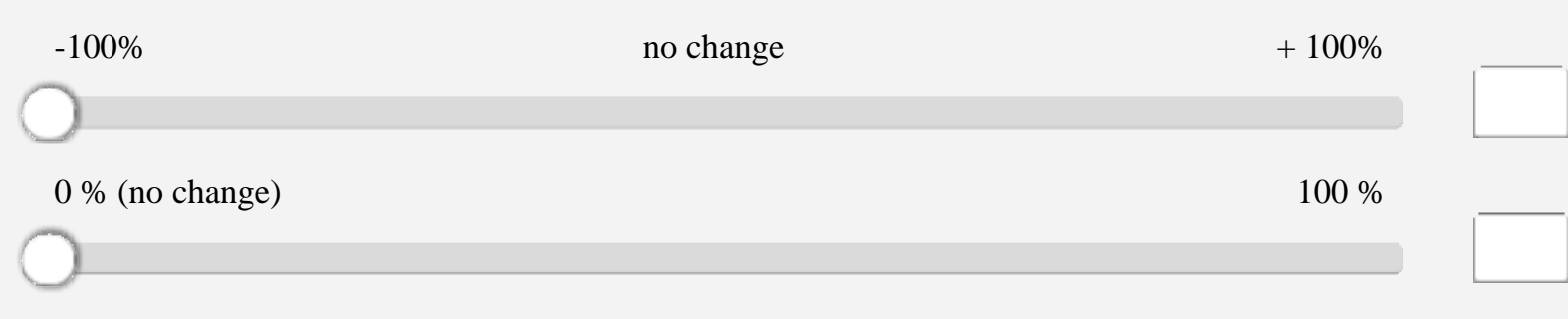

Of your monthly expenses, what percentage goes toward payments for things that no longer generate revenue? (e.g., indoor dining space that can't be used, office space that is not currently occupied? If nothing has changed please select "no change."

For how many years has your business been at its current location? 
What is your role with the business?

Owner Senior employee (5+ years at the business)
Manager
Assistant Manager I do not have a formal role

How would you describe your business? Check ALL options that apply

Woman-owned business * (the business need not be Federally registered as such)

Minority-owned * (the business need not be Federally registered as such)

Veteran-owned * (the business need not be Federally registered as such)

Other (please specify)

Please indicate your ethnicity.
Hispanic or Latino
Not Hispanic or Latino
Prefer not to respond

Please indicate your race. (Select one or more)

American Indian or Alaska Native

Asian

Black or African American

Native Hawaiian or other Pacific Islander

White

Prefer not to respond 
How would you describe your business' ownership structure? Check ALL that apply

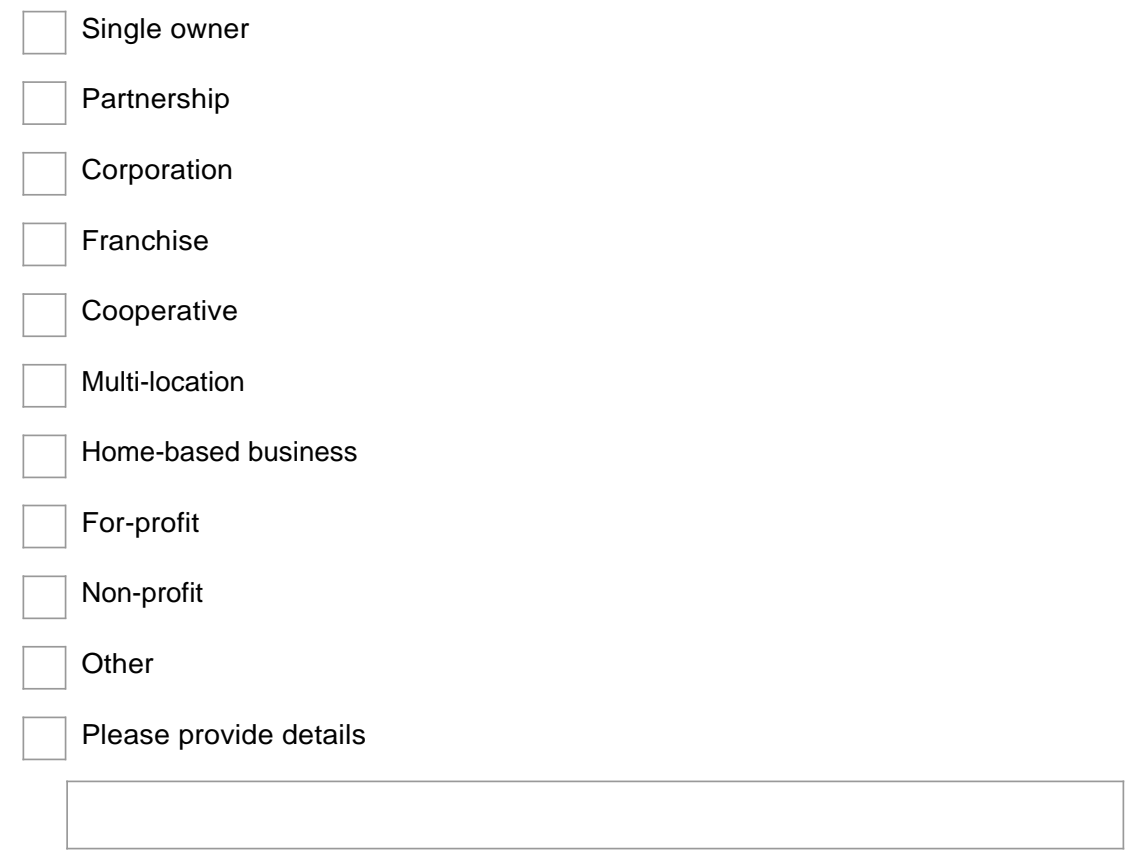

Is anyone employed by your business disabled?

Yes
No
Unsure


Please indicate your level of agreement with the following statements. (1 = least

agreement and $\mathbf{5}=$ greatest agreement)

(least agreement)
5

(greatest agreement)

COVID-19 did not impact

my business in any

significant manner

COVID-19 posed the

greatest risk yetto my

organization's survival

The impacts of COVID- 19

will leave my organization

unable to cope with a

natural disaster, should one

occur, in the next year

\section{I am not concerned}

about a second wave of

COVID-19 and the

potential effects on my

organization

Stress on my business from

COVID-19 has created

increased stress in my home

life

Stress in my home life from COVID-19 has created increased stress

for my business

Please provide your first name and your business email address, below. We'd like to follow-up with you on your responses and send a report of the findings for this wave of data collection and request your participation in a possible third wave.

E-mail address

First name

Is there anything else you would like to share at this time? 


\section{THANK YOU}

If there is anything you would like us to know, please feel free to follow-up with us at SMEResearch@nist.gov

A Federal agency may not conduct or sponsor, and a person is not required to respond to, nor shall a person be subject to a penalty for failure to comply with an information collection subject to the requirements of the Paperwork Reduction Act of 1995 unless the information collection has a currently valid OMB Control Number. The approved OMB Control Number for this information collection is 06930078 . Without this approval, we could not conduct this survey/information collection. Public reporting for this information collection is estimated to be approximately 15 minutes per response, including the time for reviewing instructions, searching existing data sources, gathering and maintaining the data needed, and completing and reviewing the information collection. All responses to this information collection are voluntary. Send comments regarding this burden estimate or any other aspect of this information collection, including suggestions for reducing this burden to the National Institute of Standards and Technology (NIST). Attn: Dr. Jennifer Helgeson, NIST, 100 Bureau Drive, MS 8603, Gaithersburg, MD 20899-1710, telephone 301-975-6133, or via email: jennifer.helgeson@nist.gov 


\section{Appendix D: Wave 2B Survey (English)}

\section{Small- and Medium-Sized Business Complex Event COVID-19 Survey (Wave 2)}

OMB Control \# 0693-0078 Expiration

07/31/2022

Thank you for responding to our initial survey during Summer 2020. The information learned was invaluable and was developed into reports and suggested actions for businesses like yours and the institutions that serve them.

We understand that the COVID-19 pandemic may still be disrupting your business. Your continued participation is critical for the development of guidance on how businesses like yours are adapting to the current circumstances.

Please spend a few minutes filling out this follow-up survey. We ask for no sensitive information and we will not identify you or your business. If your business has more than one location, please answer for only one location. We'd like to learn about practices taken that have helped reduce the impact of COVID-19, especially in the face of future hazard events.

You may skip any questions or exit the survey at any time.

This survey should take less than 15 minutes to complete. You may opt to receive aggregate results of the survey (at the end).

Both your perspective and time are exceptionally invaluable, especially during these uncertain times. Our efforts will be greatly enhanced if you choose to participate.

Thank you for your time and participation. Jennifer

SMEResearch@nist.gov

* What is the current status of your business?

Fully open with the same products and services as pre-COVID-19

Open, but with fewer or different products or services

Temporarily closed, but plan to reopen

Permanently closed 


\section{Small- and Medium-Sized Business Complex Event COVID-19 Survey (Wave 2)}

[if closed]

Approximately when did your business close?

Date / Time

Date

MM/DD/YYYY

Was the business closure related to the COVID-19 pandemic?

Yes

$\mathrm{No}$

Other

Please explain

Did the business experience other issues that contributed to the closure? Please select all that apply.

Natural hazard or extreme weather impacts

Market/Financial volatility (e.g., lower productivity, supply chain disruption, operational issues)

Public health concerns / illness (e.g., ability to keep customers or yourself safe)

Workforce issues (e.g., workforce safety, rehiring/replacing/retaining workforce)
Consumer-side issues (e.g., preferences for online shopping, reduction in foot traffic)

Personal reasons (e.g. family responsibilities, personal financial hardships, retirement)

Other

Please provide details 
Did the business implement any of the following before permanently closing? Please select all that apply

Laid off some of the workforce

Reduced salaries

Sold some assets

Increased debt/borrowing
Converted product lines or services offered

Received government (national or local) support

Other

Please provide details 
6.9. Do you expect that the business will open again in the future?

Yes
No
Maybe / Unsure

Please provide details 


\section{Small- and Medium-Sized Business Complex Event COVID-19 Survey (Wave 2)}

When was your business allowed to operate in your jurisdiction after the start of the COVID-19 pandemic? (an approximate date is fine) Please respond with a date after March 13, 2020. If your business never closed, please select March 13, 2020.

Date

Date

\section{MM/DD/YYYY}

How would you describe the impact you are currently experiencing from COVID-19?

It is NOT impacting my business

It is starting to impact my business

It is continuing to impact my business

The impact is on the decline

The impact is over

It has had a POSITIVE impact on my business

What are the most important factors that influenced the choice of whether or not to resume operations or to continue operations if they never ceased? (Please select no more than 5)

Local business opening guidance

Employee safety

Change in customers

Disruption to supply/inventory delivery

University and school opened/closed

Nearby businesses opened/closed

Local government information/suggestion

Level of concern about infection (self, employees, customers, and/or suppliers)
Availability of personal protective equipment and/or cleaning supplies

Absenteeism

Staff's desire to return to work

Media coverage

Business margins

Costs to comply with COVID-19 requirements (e.g., installation of plexiglass dividers)

Does not apply to my business

Other

Please provide details 
How has the COVID-19 pandemic impacted the operation of your organization during the period AUGUST 1, 2020 to today?

Does NOT apply to my

Stopped operations due to external mandate

Stopped operations due

to financial issues

Decrease in revenue

Increase in revenue

Problems with my supply

chain/receiving or shipping

inventory

Issues with delivery of

products to customers

Decrease in customers

Increase in customers

Please provide details

What is the approximate percent CHANGE in employees at your business compared to this time LAST year? (negative values indicate a reduction in workforce)

$-100 \%$
NO change
$100 \%$ 
Since the start of the COVID-19 pandemic (March 13, 2020) has your business RECEIVED any of the following financial assistance? (please check all that apply)

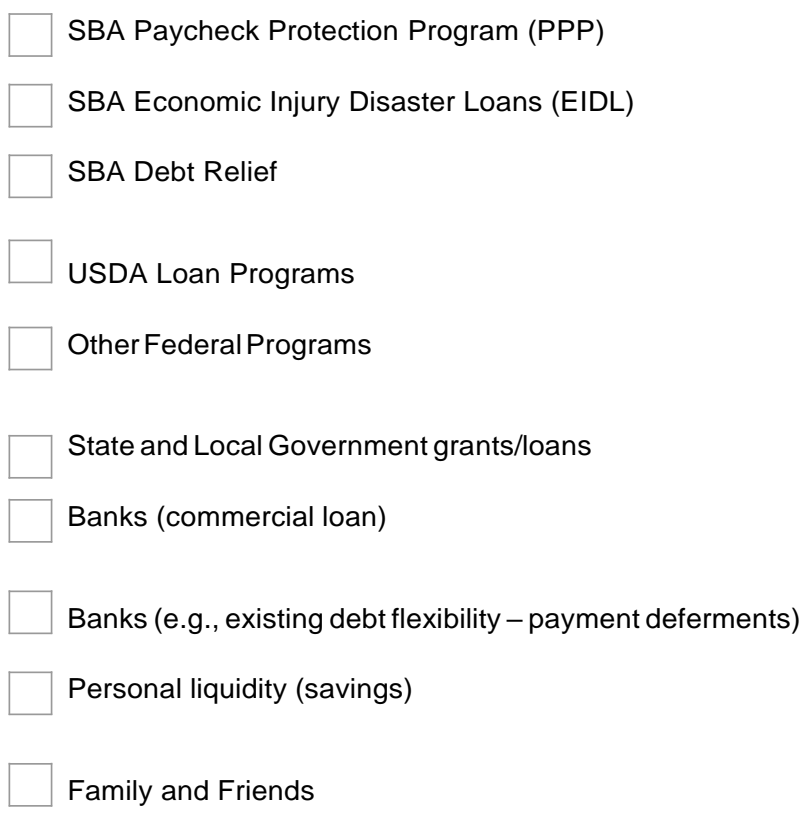

Please provide details

Since the start of the COVID-19 pandemic has your business been DECLINED for assistance by any source sought? (the source can be informal or formal)

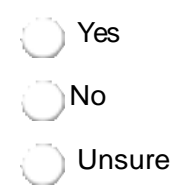

Please describe 
Please describe anything your business has started or continues to do to address the COVID-19 pandemic. (Please answer for the period August 1, 2020 to the present only.) Please check all that apply.

Changed products or services offered to consumers

Reduced staff

Reduced number of people allowed within the business space

Allowed employees (some or all) to work remotely

Offered contactless pick-up or delivery

Increased e-commerce

Negotiated longer payment terms for suppliers so the company can keep its cash longer

Curb-side pick-up made available

Collected money owed from customers as early as possible

Renegotiated or gave-up lease

Renegotiated current and future prices with my suppliers

Prioritized inventories to some customers

Exchanged resources or information with other organizations

Reallocated products based on inventory levels

Exchanged inventory with another business (to fill a gap)

Implemented short-term alliances with my suppliers and/or competition

Increased staff

None

Does not apply to my business

Other

Please provide details

If you had the information and experience you have today, would you have made different choices for your business at the start of the COVID-19 pandemic?

Yes, definitely

Maybe

No, definitely not

Not sure

Please specify what you may have done differently. 


\section{Small- and Medium-Sized Business Complex Event COVID-19 Survey (Wave 2)}

The section asks you about risks from natural hazards and extreme weather. We are interested in your business' experience in the past and planning for the future.

What natural hazard(s) is/are of the greatest concern for your business' location? (select all that apply)

$\begin{array}{ll}\square & \text { Coastal storms } \\ \square & \text { Drought/water scarcity } \\ \square & \text { Earthquake } \\ \square & \text { Extreme cold } \\ \square & \text { Extreme heat/heat waves } \\ \square & \text { Flooding } \\ \square & \text { Hurricane } \\ \square & \text { Storm surge }\end{array}$

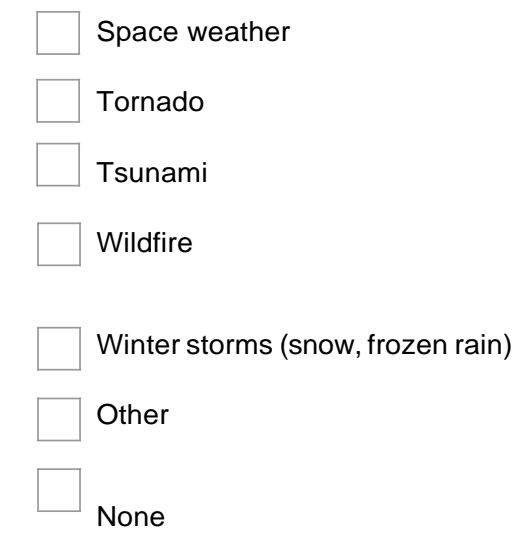

Since AUGUST 1, 2020 have any of these natural hazard events occurred at your location?

Yes, with severe negative impacts
Yes, with minor negative impacts

Yes, with no negative impacts 


\section{Small- and Medium-Sized Business Complex Event COVID-19 Survey (Wave 2)}

Was your business' response to this event impacted by COVID-19?

$$
\begin{aligned}
& \text { Yes } \\
& \text { No } \\
& \text { Unsure }
\end{aligned}
$$

\section{Please provide details}

How did the event impact your business compared to similar events before COVID-19?

Greater impact than in the past

Similar significance to past experience(s)

Less significant than past experience(s)

First time such an event impacted my business 


\section{Small- and Medium-Sized Business Complex Event COVID-19 Survey (Wave 2)}

Was the impact greater than in the past because of the nature of the natural hazard or extreme weather event (e.g., hurricane category or wildfire strength)?

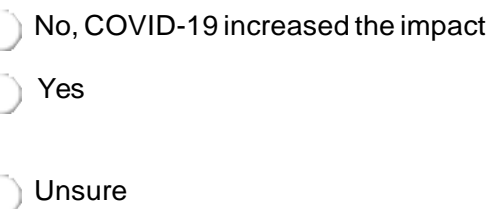

Have actions taken by your business to prepare for natural disasters helped to address the impacts of COVID-19?

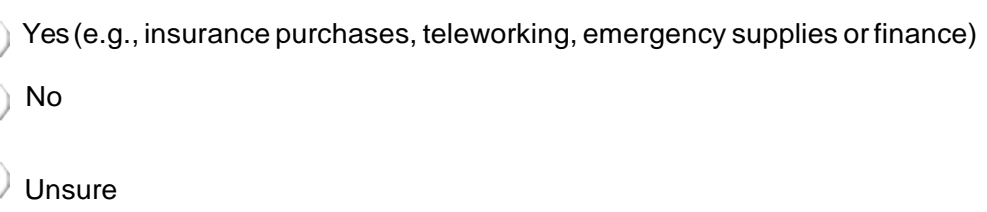

Please provide details

Do you plan to adopt any of the practices used during the COVID-19 pandemic in anticipation of future natural hazards?

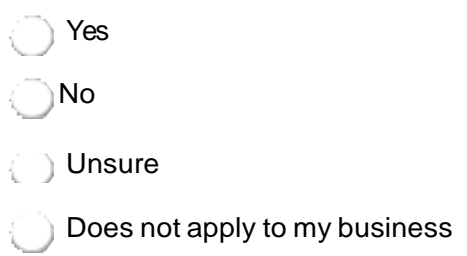

Please provide details

How has your ability to prepare for natural hazards in the future been affected by the impact of COVID-19 on your business?

It makes it significantly harder

It makes it somewhat harder

It has not changed
It makes it somewhat easier

It makes it significantly easier

Does not apply to my business 
This section asks you about your busines' future plans.

Do natural hazards / weather events and potential impacts of these events cause concern for your business?

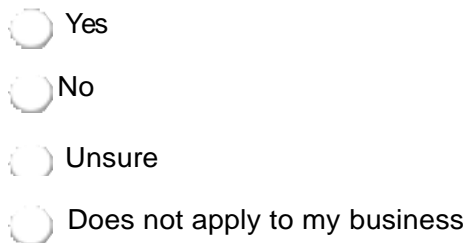




\section{Small- and Medium-Sized Business Complex Event COVID-19 Survey (Wave 2)}

Have you implemented steps to reduce business risks related to natural hazard / weather events and potential impacts?

Yes, already implemented

Yes, in the process of implementation

Yes, planning to implement

No, but would like to learn more
No, do not plan to do so

No, I don't feel that there is anything I can do

Unsure

Please provide details

Do market or financial volatility (e.g., supply chain disruption, operational issues) cause concern for your business?

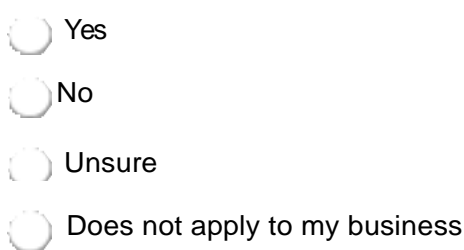




\section{Small- and Medium-Sized Business Complex Event COVID-19 Survey (Wave 2)}

Have you implemented steps to reduce business risks related to market or financial volatility?

Yes, already implemented

Yes, in the process of implementation

Yes, planning to implement

No, but would like to learn more
No, do not plan to do so

No, I don't feel that there is anything I can do Unsure

\section{Please provide details}

Will a subsequent wave of COVID-19 associated restrictions cause concern for your business?
Yes
Unsure
Does not apply to my business

No 


\section{Small- and Medium-Sized Business Complex Event COVID-19 Survey (Wave 2)}

Have you implemented steps to reduce business risks related to a potential additional wave of COVID-19 associated restrictions?

Yes, already implemented

Yes, in the process of implementation

Yes, planning to implement

No, but would like to learn more
No, do not plan to do so

No, I don't feel that there is anything I can do Unsure

Please provide details

Do other public health issues (e.g., flu season) cause concern for your business?

Yes

No

Unsure

Does not apply to my business 


\section{Small- and Medium-Sized Business Complex Event COVID-19 Survey (Wave 2)}

Have you implemented steps to reduce business risks from other public health concerns?

Yes, already implemented

Yes, in the process of implementation

Yes, planning to implement

No, but would like to learn more

Please provide details

Do workforce issues (e.g., workforce safety, workforce reduction, absenteeism, retaining/rehiring staff) cause concern for your business?

Yes

No

Unsure

Does not apply to my business
No, do not plan to do so

No, I don't feel that there is anything I can do Unsure

) 


\section{Small- and Medium-Sized Business Complex Event COVID-19 Survey (Wave 2)}

Have you implemented steps to reduce business risks from workforce concerns?

Yes, already implemented

Yes, in the process of implementation

Yes, planning to implement

No, but would like to learn more

Please provide details

Do consumer-side issues (e.g., preferences for online shopping, reductions in foot traffic, low holiday season sales) cause concern for your business?

Yes

No

Unsure

Does not apply to my business
No, do not plan to do so

No, I don't feel that there is anything I can do Unsure 


\section{Small- and Medium-Sized Business Complex Event COVID-19 Survey (Wave 2)}

Have you implemented steps to reduce business risks from consumer-side concerns?

Yes, already implemented

Yes, in the process of implementation

Yes, planning to implement

No, but would like to learn more
No, do not plan to do so

No, I don't feel that there is anything I can do Unsure

Please provide details

Do you feel that you have the resources needed to protect your business against the risks you just identified?

$$
\begin{aligned}
& \text { Yes } \\
& \text { No } \\
& \text { Unsure }
\end{aligned}
$$

What resources, information, or support do you feel you need to be better protected against the risks you identified?

How much time do you think will pass from TODAY until your business returns to its pre-COVID-19 conditions (e.g., operational level)?
Already there
1 month or less
2-3 months
4-6 months
6-12 months

12-18 months

More than 18 months

Unlikely to resume operations at that level

Unlikely to resume operations atall

Unsure

Please provide details 
This section asks you to provide some information about your business and yourself.

Before COVID-19 what was the typical monthly revenue for your business (not including any financial assistance or loans)? Please use this time in 2019 for reference.

$\$ 0-\$ 500$

$\$ 501-\$ 2,500$

$\$ 2,501-\$ 5,000$

$\$ 5,001-\$ 15,000$

$\$ 15,001-\$ 50,000$

$\$ 50,001-\$ 125,000$
$\$ 125,001-\$ 200,000$

$\$ 200,001-\$ 500,000$

$\$ 500,001-\$ 1,000,000$

$\$ 1,000,001$ or more

Unsure

Prefer not to respond

What percent change did you see in monthly revenue due to COVID-19 last month relative to that time last year?

$-100 \%$

$\bigcirc$

$0 \%$ (no change) no change

$+100 \%$

$100 \%$

Of your monthly expenses, what percentage goes toward payments for things that no longer generate revenue? (e.g., indoor dining space that can't be used, office space that is not currently occupied? In nothing has changed please selection "no change"

For how many years has your business been at its current location?

What is your role with the business?

Owner

Manager

Assistant Manager

Senior employee (5+ years at the business)

Employee

I do not have a formal role 
How would you describe your business? Check ALL options that apply

Woman-owned business * (the business need not be

Federally registered as such)

Family-owned * (the business need not be Federally registered as such)

Minority-owned * (the business need not be Federally registered as such)

Immigrant-owned

Veteran-owned * (the business need not be Federally registered as such)

Other (please specify)

Please indicate your ethnicity.

Hispanic or Latino

Not Hispanic or Latino

Prefer not to respond

Please indicate your race. (Select one or more)

American Indian or Alaska Native

Asian

Black or African American

Native Hawaiian or other Pacific Islander

White

Prefer not to respond 
How would you describe your business' ownership structure? Check ALL that apply

$\begin{array}{ll}\text { Single owner } & \text { Multi-location } \\ \text { Partnership } & \text { Home-based business } \\ \text { Corporation } & \text { For-profit } \\ \text { Franchise } & \text { Non-profit } \\ \text { Cooperative } & \text { Other }\end{array}$

Please provide details

Is anyone employed by your business disabled?

Yes
No
Unsure 
Please indicate your level of agreement with the following statements. (1 = least

agreement and $\mathbf{5}=$ greatest agreement)

1 (least agreement)

2

3

4

5

(greatest agreement)

COVID-19 did not

impact my business in

any significant manner

COVID-19 posed the greatest risk yet to my organization's survival

The impacts of COVID-

19 will leave my organization unable to cope with a natural disaster, should one occur, in the next year

I am not concerned about a second wave of COVID-19 and the potential effects on my organization

Stress on my business from COVID-19 has created increased stress in my home life

Stress in my home life from COVID-19 has created increased stress for my business

Please provide your first name and your business email address, below. We'd like to follow-up with you on your responses and send a report of the findings for this wave of data collection and request your participation in a possible third wave.

E-mail address

First name

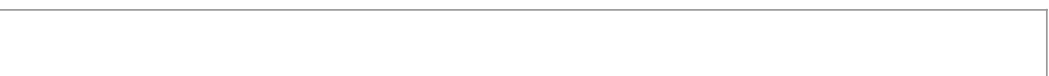

Is there anything else you would like to share at this time? 


\section{THANK YOU}

If there is anything you would like us to know, please feel free to follow-up with us at SMEResearch@nist.gov

A Federal agency may not conduct or sponsor, and a person is not required to respond to, nor shall a person be subject to a penalty for failure to comply with an information collection subject to the requirements of the Paperwork Reduction Act of 1995 unless the information collection has a currently valid OMB Control Number. The approved OMB Control Number for this information collection is 06930078 . Without this approval, we could not conduct this survey/information collection. Public reporting for this information collection is estimated to be approximately 15 minutes per response, including the time for reviewing instructions, searching existing data sources, gathering and maintaining the data needed, and completing and reviewing the information collection. All responses to this information collection are voluntary. Send comments regarding this burden estimate or any other aspect of this information collection, including suggestions for reducing this burden to the National Institute of Standards and Technology (NIST). Attn: Dr. Jennifer Helgeson, NIST, 100 Bureau Drive, MS 8603, Gaithersburg, MD 20899-1710, telephone 301-975-6133, or via email: jennifer.helgeson@nist.gov 


\section{Appendix E: Wave 2B Survey (Spanish)}

\section{Encuesta Empresarial: Impacto y Recuperación de COVID-19}

Control OMB \# 0693-0078

\section{Fecha de Expiración 07/31/2022}

Entendemos que la pandemia de COVID-19 puede estar interrumpiendo las operaciones en su negocio. Con esta encuesta, esperamos conocer cómo las empresas como la suya se están adaptando a las circunstancias y cómo esto puede o no estar relacionado con factores climáticos estresantes más generales que su empresa puede enfrentar.

Tanto su perspectiva como su tiempo son excepcionalmente valiosos, especialmente durante estos tiempos inciertos. Nuestros esfuerzos mejorarán enormemente si puede dedicar unos minutos completando esta encuesta. No solicitamos información confidencial y no lo identificaremos a usted ni a su empresa. Si su empresa tiene más de una ubicación, responda solo por una.

El propósito de esta encuesta es comprender qué apoyo necesitan las empresas como la suya y comunicar estas necesidades a quienes puedan brindar asistencia. Nos gustaría conocer las prácticas tomadas que han ayudado a reducir el impacto de COVID-19, especialmente frente a eventos de riesgo futuros.

Si se siente incómodo respondiendo alguna de las preguntas, puede omitirlas o salir de la encuesta en cualquier momento.

Esta encuesta debería tomar menos de 15 minutos para completar. Puede optar por recibir resultados agregados (al final).

Gracias por su tiempo y participación. Jennifer

Oficina de Economía Aplicada, Instituto Nacional de Estándares y Tecnología SMEResearch@nist.gov

* Cual es el estado actual de su negocio?

Completamente abierto con los mismos productos y servicios suministrados antes de COVID-19

Abierto, pero con una menor cantidad o diferentes productos o servicios

Temporalmente cerrado, pero planeo reabrir

Permanentemente cerrado 


\section{Encuesta Empresarial: Impacto y Recuperación de COVID-19}

Aproximadamente, ¿cuándo cerró su negocio?

Fecha/Hora

Fecha

MM/DD/AAAA

¿Estuvo el cierre del negocio relacionado con la pandemia de COVID-19?

Sí

No

Otro

Por favor especifique

¿El negocio sufrió otros problemas que contribuyeron al cierre? Por favor seleccione todos los que apliquen

Peligros naturales o impactos climáticos extremos

Volatilidad financiera/de mercado (p.ej., menor productividad, interrupción de la cadena de suministro, problemas operativos)

Preocupaciones de salud pública/enfermedades (p.ej., habilidad para mantener la seguridad de los clientes o la suya)

Problemas de los trabajadores (p.ej., seguridad de los trabajadores, recontratación/reemplazo/retención de los trabajadores)
Problemas del lado de los clientes (p.ej., preferencias por compras online, reducción de tráfico en el local)

Razones personales (p.ej., responsabilidades familiares, dificultades económicas personales, retiro)

Otro 
6.10. ¿El negocio implementó alguno de los siguientes antes de su cierre permanente? Por favor, seleccione todas las opciones que aplique.

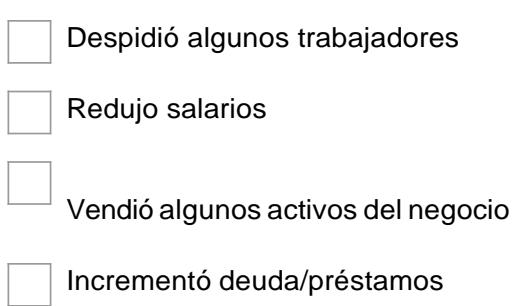

Convirtió líneas de producto o servicios ofrecidos Recibió apoyo gubernamental (nacional o local) Otro

Por favor, proporcione detalles

6.11. ¿Usted espera abrir su negocio nuevamente en el futuro?

Sí
No
Quizá/Inseguro

Por favor, proporcione detalles 


\section{Encuesta Empresarial: Impacto y Recuperación de COVID-19}

¿Cuándo se le permitió a su negocio operar en su jurisdicción después del inicio de la pandemia de COVID- 19? (una fecha aproximada es aceptable). Por favor responda con una fecha posterior a marzo 13, 2020. Si su negocio nunca cerró, por favor seleccione marzo 13, 2020.

Fecha

\section{MM/DD/AAAA}

¿Cómo describiría el impacto que está experimentando actualmente por la pandemia COVID-19?

NO está impactando mi negocio

Está comenzando a impactar mi negocio

Continúa impactando mi negocio
El impacto está en disminución

El impacto ha terminado

El impacto sobre mi negocio ha sido POSITIVO

¿Cómo ha impactado la pandemia de COVID-19 la continuidad /estabilidad de sus operaciones diarias? Por favor responda si una acción ocurrió durante ALGUNO o TODOS los períodos de tiempo comprendidos entre marzo 13 - julio 31 y agosto 1 - presente.

Marzo 13 - Julio31, 2020

Permaneció

completamente abierto

Redujo días/horas

Cerrado al público

Todo el personal trabaja desde casa

Algunos miembros del personal trabajan desde casa

Se adicionaron servicios

Se incrementó el comercio electrónico

Por favor proporcione detalles
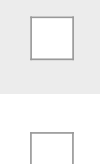

$\square$
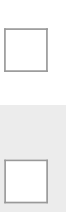

Agosto 1, 2020 - Presente

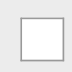


¿Cómo ha impactado la pandemia de COVID-19 las operaciones de su negocio? Por favor responda si una acción ocurrió durante ALGUNO o TODOS los períodos de tiempo comprendidos entre marzo 13 - julio $31 \mathrm{y}$ agosto 1 - presente.

Marzo 13 - Julio31, 2020

Agosto 1, 2020 - Presente
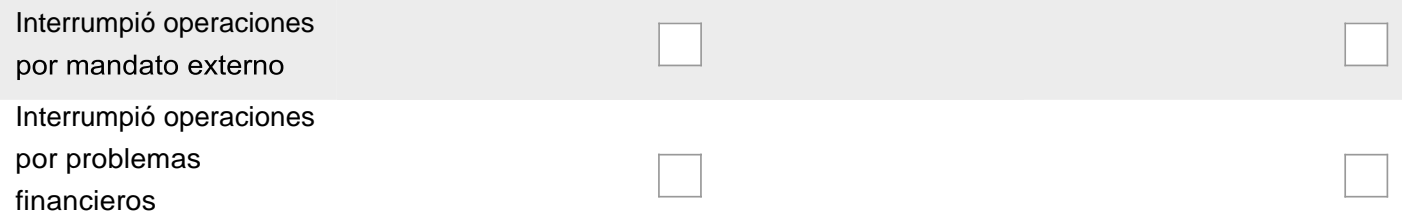

Aumentaron los ingresos

Problemas con mi cadena de suministro / recepción o envío de inventario

Problemas con la entrega de productos a los clientes

Disminución de clientes

Aumento de clientes

Por favor proporcione detalles 
¿Cuáles son los factores más importantes que influenciaron la decisión de reanudar o no las operaciones o de continuar operaciones si nunca se detuvieron? (Por favor, no seleccione más de 5)

Orientación para la apertura de negocios locales

Seguridad de los empleados

Cambio de clientes

Interrupción en el suministro/entrega de inventario

Apertura/cierre de universidad/escuela

Apertura/cierre de negocios cercanos

Información/sugerencia del gobierno local

Nivel de preocupación acerca de la infección (mía, empleados, clientes, y/o proveedores)

Disponibilidad de equipo de protección personal y/o suministros de limpieza

Absentismo

Deseo del personal de regresar al trabajo

Cobertura en los medios de comunicación

Márgenes de rentabilidad delnegocio

Costos para cumplir con requerimientos de COVID-19 (p.ej., instalación de divisores plexiglás)

Aprobación/despliegue de vacuna para COVID-19

Paquete de ayuda económica de diciembre contra COVID-19

No aplica a mi negocio

Otro (por favor proporcione detalles) 
Desde el inicio de la pandemia COVID-19 (marzo 13, 2020), ¿su negocio ha requerido y/o recibido alguna de las siguientes ayudas financieras? (Por favor escoja todas las que apliquen)

Requerido

Recibido

NO Recibido

Programa de Protección

de Cheques de Pago de

SBA (SBA Paycheck

Protection Program

PPP)

Préstamos de Daño

Económico por

Desastres de SBA (SBA

Economic Injury Disaster

Loans EIDL)

Otros Programas

Federales

Subvenciones /

préstamos del Gobierno

Estatal y Local

Bancos

Liquidez personal

(ahorro)

Familia, amigos,

financiación colectiva

(Crowdfunding)

Aplazamiento en los pagos (renta, servicios públicos)

\section{Este negocio no ha}

buscado asistencia

financiera de ninguna

fuente

No estoy seguro

No aplica a mi negocio

Por favor, proporcione detalles

Por favor, describa cualquier cambio que su organización haya realizado o siga realizando para enfrentar la pandemia de COVID-19. Por favor responda si su negocio llevó a cabo alguna acción durante ALGUNO o TODOS los períodos de tiempo.

Marzo 13 - Julio31, 2020

Agosto 1, 2020 - Presente

Modifiqué productos o

servicios ofrecidos a los

clientes 
Reduje el número de clientes permitidos simultáneamente dentro del espacio del local

Ofrecí recogida o entrega sin contacto Incrementé el comercio electrónico

Habilité el servicio para recoger el producto fuera del local

Renegocié o suspendí el arriendo del local

Prioricé inventarios para algunos clientes

Reasigné productos basados en niveles de inventario

Intercambié inventarios con otros negocios (para cubrir faltantes)

Incrementé el personal

Reduje el personal

Permití a los empleados (algunos o todos) trabajar de forma remota

Negocié plazos de pago más largos para los proveedores para que la compañía pueda mantener su efectivo por más tiempo

Recaudé dinero de los clientes lo antes posible

Renegocié los precios actuales y futuros con mis proveedores Intercambié recursos o información con otras organizaciones

Implementé alianzas a corto plazo con mis proveedores y / o competencia 
No aplica a mi negocio

Otro

Por favor proporcione detalles

¿Si usted tuviera la información y experiencia que tiene hoy, habría tomado decisiones diferentes para su negocio al inicio de la pandemia de COVID-19?

Sí, definitivamente
Quizá
No, definitivamente no
No estoy seguro

Por favor especifique qué habría hecho diferente 
Esta sección pregunta sobre riesgos derivados de peligros naturales y eventos climáticos extremos. Estamos interesados en la experiencia que su negocio ha tenido en el pasado y su planeación para el futuro.

¿Qué evento(s) natural(es) es(son) de mayor preocupación en la ubicación de su negocio? (seleccione todas las opciones que correspondan)

\begin{tabular}{|c|c|}
\hline Tormentas costeras & Clima espacial \\
\hline Sequía / Escasez de agua & Tornados \\
\hline Terremoto & isumamis \\
\hline Frío extremo & Incendios forestales \\
\hline Calor extremo / Olas de calor & Tormentas de invierno (nieve, lluvia congelada) \\
\hline Inundaciones & Uiro \\
\hline Huracanes Marejadas & Ninguno \\
\hline
\end{tabular}

¿Cuántos de estos tipos de evento han afectado su negocio en los últimos 10 años? Un valor estimado es suficiente. "Afectado" significa al menos un día de cierre.

0

¿Alguno de estos eventos de peligro natural ocurrió en su negocio durante el periodo comprendido entre marzo 13 de 2020 hasta el presente?

Sí, con impactos negativos severos

Sí, con impactos negativos menores

Sí, sin impactos negativos

No

No estoy seguro

No aplica a mi negocio 


\section{Encuesta Empresarial: Impacto y Recuperación de COVID-19}

¿La respuesta de su negocio a este evento estuvo impactada por COVID-19?

Sí

No

No estoy seguro

No aplica a mi negocio

Por favor proporcione detalles

¿Cómo impactó el evento a su negocio en comparación a eventos similares antes de COVID-19?

Mayor impacto que en el pasado

De importancia similar a experiencias anteriores

Menos significativo que experiencias anteriores
Crimera vez que tal evento impacta mi negocio

No aplica a mi negocio 


\section{Encuesta Empresarial: Impacto y Recuperación de COVID-19}

¿El impacto fue mayor que en el pasado debido a la naturaleza del peligro natural o evento climático extremo (p.ej., categoría de huracán 0 intensidad del incendio forestal)?

No, COVID-19 incrementó el impacto

Sí

No estoy seguro

¿Qué tipo de acciones ha tomado su negocio en el pasado (antes de COVID-19) para enfrentar los peligros naturales?

Edificio(s) a prueba de inundaciones - permanente (p.ej., compuerta de inundación)

Edificio(s) a prueba de inundaciones - temporal (p.ej., bolsas de arena, puertas de embarque)

Asegurar una ubicación de almacenamiento alterna o secundaria

Evaluar el edificio para garantizar que la construcción cumpla con los estándares de los códigos de construcción

Realizar una evaluación de riesgos para identificar vulnerabilidades en el negocio (ante peligros específicos)

Adoptar estrategias para mantenerme informado sobre las alertas y advertencias meteorológicas (por ejemplo, NOAA Weather Radio, aplicaciones comerciales)

Asignar responsabilidades por desastre (es decir, función de gestión de emergencias) a empleados específicos

Realizar simulacros de seguridad regularmente (por ejemplo, refugio en el lugar, evacuaciones, árbol telefónico)
Hacer una copia de seguridad de todos los documentos importantes (digitalmente o almacenados en una ubicación secundaria)

Levantar el inventario y otros suministros del suelo para evitar la exposición al agua

Realizar un chequeo del seguro para asegurar una cobertura de seguro adecuada

Desarrollar un plan de acción de emergencia / lista de verificación por escrito 
Aumentar la cobertura del seguro, si es necesario

Desarrollar / actualizar planes de teletrabajo

Establecer o aumentar la capacidad de ventas remotas / en línea

Usar cuentas de redes sociales para proporcionar información de operaciones al público (p.ej., cierres)

Minimizar la vulnerabilidad de la cadena de suministro a través de estrategias de múltipleabastecimiento

Desarrollar una conexión con los funcionarios locales de gestión de emergencias

Remover los escombros y quitar la vegetación seca lejos de las estructuras

Otro (especifique)
Tener un respaldo en la generación de energía

Mantener / harmonizar el equipo para remover escombros / nieve

Mantener un fondo de emergencia (dinero disponible para "días lluviosos")

Ninguno

No aplica a mi negocio 
¿Las acciones tomadas por su negocio para prepararse contra los desastres naturales ayudaron a enfrentar los impactos de COVID$19 ?$

Sí (p.ej., compras de seguros, teletrabajo, suministros o fondos de emergencia)

No

No estoy seguro

Por favor, proporcione detalles

¿Usted planea adoptar alguna de las prácticas usadas durante la pandemia de COVID-19 en anticipación a futuros peligros naturales?

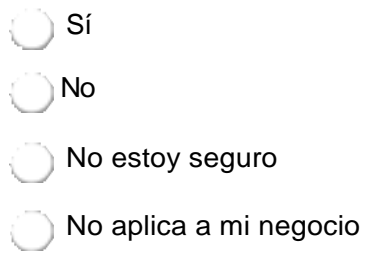

Por favor, proporcione detalles

¿Cómo se ha afectado su habilidad de prepararse para peligros naturales futuros debido el impacto de COVID-19 sobre su negocio?

Lo hace significativamente más difícil

Lo hace un poco más difícil

No ha cambiado
Lo hace un poco más fácil

Lo hace significativamente más fácil

No aplica a mi negocio 


\section{Encuesta Empresarial: Impacto y Recuperación de COVID-19}

Esta sección pregunta sobre los futuros planes de su negocio.

¿Causan preocupación a su negocio eventos de peligro natural/clima e impactos potenciales derivados de estos eventos?

$$
\text { Sí }
$$

No

No estoy seguro

No aplica a mi negocio

Por favor, proporcione detalles

¿Causa preocupación a su negocio la volatilidad de mercado o financiera (p.ej., interrupciones en la cadena de suministro, problemas operacionales)?
Sí
No
No estoy seguro
No aplica a mi negocio

¿Ha implementado pasos para reducir riesgos en el negocio relacionados con la volatilidad de mercado o financiera?

Sí, ya han sido implementados

Sí, en el proceso de implementación

Sí, planeando para implementar

No, pero me gustaría aprender más

No, no planeo hacerlo

No, no siento que haya algo que pueda hacer

No estoy seguro

Por favor, proporcione detalles 


\section{Encuesta Empresarial: Impacto y Recuperación de COVID-19}

\section{¿Causa preocupación a su negocio una ola posterior de restricciones asociadas con la pandemia COVID-19?}

$$
\begin{aligned}
& \text { Sí } \\
& \text { No } \\
& \text { No estoy seguro } \\
& \text { No aplica a mi negocio }
\end{aligned}
$$




\section{Encuesta Empresarial: Impacto y Recuperación de COVID-19}

¿Ha implementado pasos para reducir riesgos en el negocio relacionados con una ola potencial adicional de restricciones asociadas con la pandemia COVID-19?

Sí, ya han sido implementados

No, no planeo hacerlo

Sí, en el proceso de implementación

No, no siento que haya algo que pueda hacer

Sí, planeando para implementar

No estoy seguro

No, pero me gustaría aprender más

Por favor, proporcione detalles 


\section{Encuesta Empresarial: Impacto y Recuperación de COVID-19}

¿Causan preocupación a su negocio otros temas de salud pública (p.ej., gripa estacional)?

Sí

No

No estoy seguro

No aplica a mi negocio 


\section{Encuesta Empresarial: Impacto y Recuperación de COVID-19}

¿Ha implementado pasos para reducir riesgos en el negocio relacionados con otras preocupaciones de salud pública?

Sí, ya han sido implementados

Sí, en el proceso de implementación

Sí, planeando para implementar

No, pero me gustaría aprender más
No, no planeo hacerlo

No, no siento que haya algo que pueda hacer

No estoy seguro

Por favor, proporcione detalles 


\section{Encuesta Empresarial: Impacto y Recuperación de COVID-19}

¿Causan preocupación a su negocio temas relacionados con la fuerza laboral (p.ej., seguridad de los trabajadores, reducción de la fuerza laboral, absentismo, retención/recontratación del personal)?
Sí
No
No estoy seguro
No aplica a mi negocio 


\section{Encuesta Empresarial: Impacto y Recuperación de COVID-19}

¿Ha implementado pasos para reducir riesgos en el negocio relacionados con otras preocupaciones de salud pública?

Sí, ya han sido implementados

Sí, en el proceso de implementación

Sí, planeando para implementar

No, pero me gustaría aprender más
No, no planeo hacerlo

No, no siento que haya algo que pueda hacer

No estoy seguro

Por favor, proporcione detalles 


\section{Encuesta Empresarial: Impacto y Recuperación de COVID-19}

¿Causan preocupación a su negocio temas relacionados con los consumidores (p.ej., preferencias para compras por Internet, reducción en el tráfico del negocio, bajas ventas de temporada)?

Sí

No

No estoy seguro

No aplica a mi negocio 
¿Ha implementado pasos para reducir riesgos en el negocio relacionados con otras preocupaciones de salud pública?

Sí, ya han sido implementados

Sí, en el proceso de implementación

Sí, planeando para implementar

No, pero me gustaría aprender más

Por favor, proporcione detalles
No, no planeo hacerlo

No, no siento que haya algo que pueda hacer No estoy seguro 


\section{Encuesta Empresarial: Impacto y Recuperación de COVID-19}

¿Siente que tiene los recursos que necesita para proteger su negocio contra los riesgos que identificó anteriormente?

Sí

No

No estoy seguro

¿Qué recursos, información o apoyo cree que necesita para estar mejor protegido contra los riesgos que identificó?
¿Cuánto tiempo cree que pasará desde HOY hasta que su negocio regrese a sus condiciones previas a COVID (p.ej., nivel operacional)?
Ya regresó a las condiciones previas a COVID-19
12-18 meses
1 mes o menos
Más de 18 meses
2-3 meses
Es poco probable que reanude las operaciones a ese nivel
4-6 mese
6-12 meses
Es poco probable que se vuelva a abrir
No estoy segur

Por favor, proporcione detalles

Esta sección le pide que proporcione algunos detalles sobre usted y su organización.

¿Qué sector describe mejor su negocio?

Construcción

Manufactura

Comercio al por menor

Servicios profesionales, científicos y técnicos

Servicios médicos y de salud

Servicios de alojamiento y alimentación

Arte, entretenimiento y recreación

Comercio al por mayor

Transporte y almacenamiento

Procesamiento de alimentos, agricultura

Finanzas y seguros

Información (p.ej., radio, periódico, televisión, telecomunicaciones)

Gestión de recursos naturales

Bienes inmuebles, alquileres y arrendamientos

Producción de combustible

Pesca / acuicultura

Turismo

Otro (por favor, especifique) 
¿Cuántas personas de tiempo completo $Y$ tiempo parcial trabajaban en este mismo establecimiento el año pasado para esta misma fecha?

$1-5$
$6-10$
$11-20$
$21-50$
$51-100$

01-150

$151-200$

$201-250$

Más de 250

Comparado con esta misma fecha el año pasado, ¿cuál es el CAMBIO porcentual aproximado en el número de empleados de este negocio? (Por favor incluya todos los empleados de tiempo completo $\mathrm{Y}$ tiempo parcial). Tenga en cuenta que un cambio negativo significa menos empleados.
$-100 \%$
no hay cambio
$+100 \%$

$\bigcirc$

Antes de COVID-19, ¿cuál era el ingreso mensual típico de su negocio (sin incluir asistencia financiera o préstamos)? Por favor, use esta misma fecha del año 2019 como referencia.

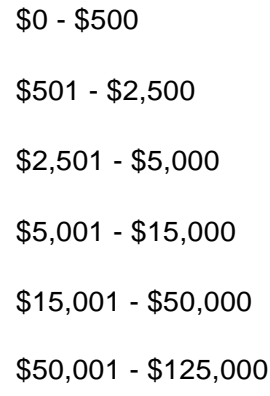

¿Qué cambio porcentual observó en el ingreso mensual del ultimo mes debido al COVID-19 en comparación con esta fecha el año pasado?

$-100 \%$

no hay cambio

$+100 \%$

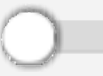

De sus gastos mensuales, ¿qué porcentaje corresponde a pagos por cosas que ya no generan ingreso (p.ej., comedor interior que no puede ser usado, espacio de oficina que actualmente no está ocupada)? Si nada ha cambiado, por favor seleccione "sin cambio".

$0 \%$ (no hay cambio)

$100 \%$ 
¿Cuántos años ha estado su negocio en esta ubicación?

¿Cuál es su papel en la organización?

Propietario

Gerente

Subgerente

Empleado senior (más de 5 años en el negocio)

Empleado

No tengo un rol formal

¿Cómo describiría su negocio? Escoja TODAS las opciones que apliquen

Negocio propiedad de una mujer *el negocio no necesita

estar registrado federalmente como tal)

Propiedad de minorías * (el negocio no necesita estar registrado federalmente como tal)

Propiedad de veteranos * (el negocio no necesita estar registrado federalmente como tal)

Otro (por favor especifique)

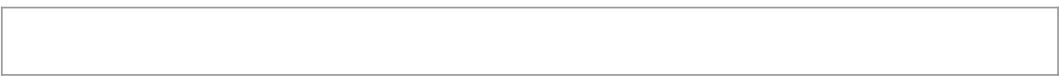

Por favor, indique su etnicidad.

Hispano o Latino

No Hispano o Latino

Prefiero no responder

Por favor, indique su raza (seleccione una o más).

Indio Americano o Nativo de Alaska

Asiático

Negro o Afroamericano

Nativo Hawaiano u otra isla del Pacífico

Blanco

Prefiero no responder 
¿Cómo describiría la estructura de propiedad de su negocio? Escoja TODAS las opciones que apliquen

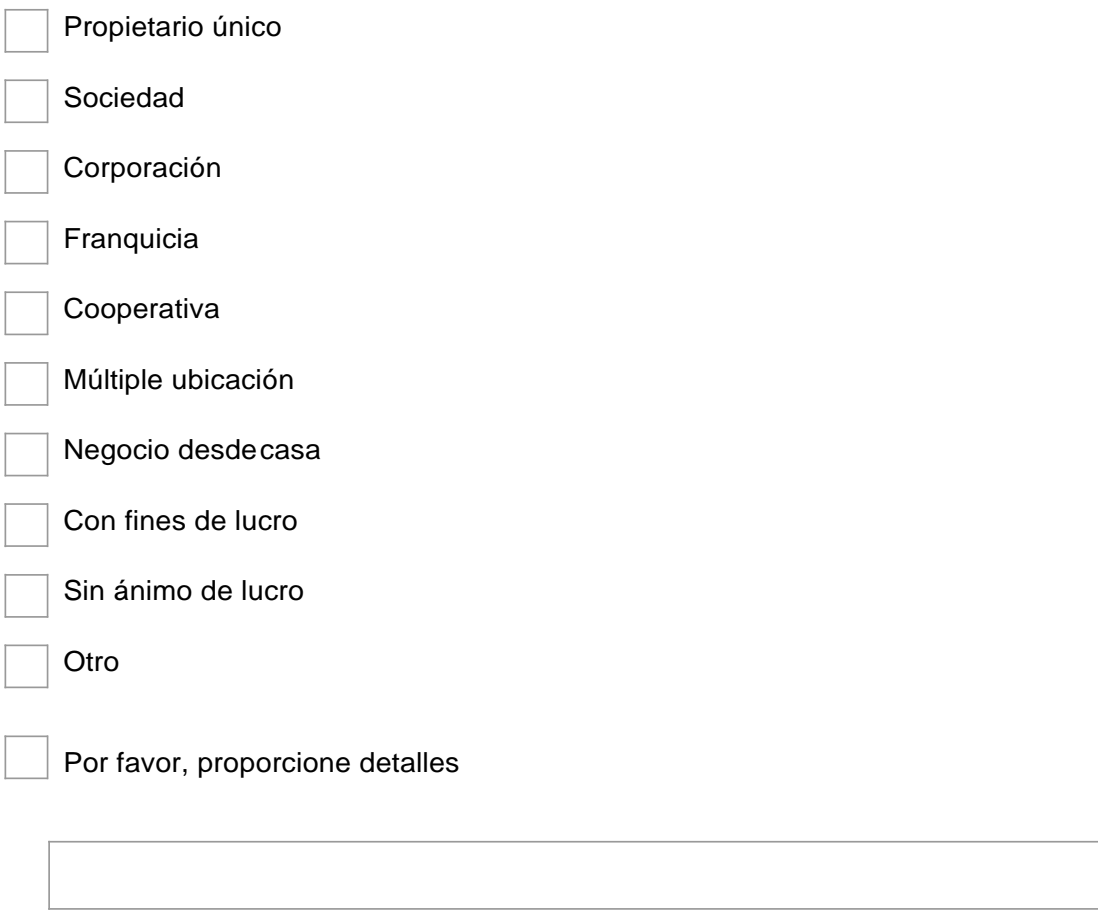

¿Alguno de los empleados de su negocio se encuentra discapacitado?

Jí

No

No estoy seguro 
Por favor, indique qué tanto usted está o no de acuerdo con las siguientes afirmaciones. (Nivel de Acuerdo 1= Muy en Desacuerdo, 5= Muy de Acuerdo)

\section{1 (muy en \\ desacuerdo)}

COVID-19 no impactó mi negocio de manera significativa

COVID-19 planteó el mayor riesgo hasta la fecha para la supervivencia de mi organización

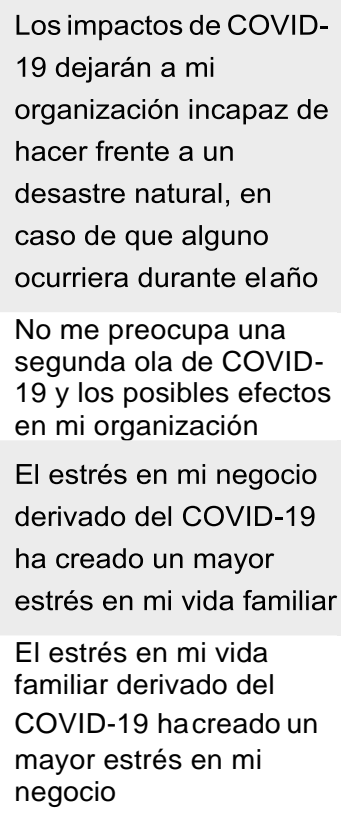

Por favor, proporcione su primer nombre y una dirección de correo electrónico empresarial. Nos gustaría hacer un seguimiento de sus respuestas con usted y enviarle un informe de los resultados de esta ola de recolección de datos y requerir su participación en una posible tercera ola.

Dirección de correo electrónico

Primer nombre

¿Hay algo más que le gustaría compartir? 


\section{¡MUCHAS GRACIAS POR COMPLETAR LA ENCUESTA!}

Si hay algo adicional que le gustaría que supiéramos, siéntase libre de contactarnos a: SMEResearch@nist.gov

Una agencia Federal no puede llevar a cabo ni patrocinar, y una persona no está obligada a responder, ni estará sujeta a una penalidad por no cumplir con recogida de información que está sujeta a los requisitos de la Ley de Reducción de Papeleo de 1995, a menos que la recogida de información tenga un Número de Control OMB válido actual. El número de control OMB aprobado para esta recogida de información es 0693 0078. Sin esta aprobación, no podríamos realizar esta encuesta / recogida de información. El informe público para esta recogida de información se estima en aproximadamente 15 minutos por respuesta, incluyendo el tiempo para revisar las instrucciones, buscar fuentes de datos existentes, recopilar y mantener los datos necesarios, y completar y revisar la recopilación de información. Todas las respuestas a esta recogida de información son voluntarias. Envíe sus comentarios sobre la estimación de carga o cualquier otro aspecto de esta recogida de información, incluyendo sugerencias para reducir esta carga al Instituto Nacional de Estándares y Tecnología (NIST). Atentamente: Dra. Jennifer Helgeson, NIST, 100 Bureau Drive, MS 8603, Gaithersburg, MD 208991710, teléfono 301-975-6133, o por correo electrónico: jennifer.helgeson@nist.govA Federal agency may not conduct or sponsor, and a person is not required to respond to, nor shall a person be subject to a penalty for failure to comply with an information collection subject to the requirements of the Paperwork Reduction Act of 1995 unless the information collection has a currently valid OMB Control Number.

The approved OMB Control Number for this information collection is 06930078 . Without this approval, we could not conduct th is survey/information collection. Public reporting for this information collection is estimated to be approximately 15 minutes per response,

including the time for reviewing instructions, searching existing data sources, gathering and maintaining the data needed, and completing and reviewing the information collection. All responses to this information collection are voluntary. Send comments regarding this burden estimate or any other aspect of this information collection, including suggestions for reducing this burden to the National Institute of Standards and Technology (NIST). Attn: Dr. Jennifer Helgeson, NIST, 100 Bureau Drive, MS 8603, Gaithersburg, MD 208991710, telephone 301-975-6133, or via email: 
